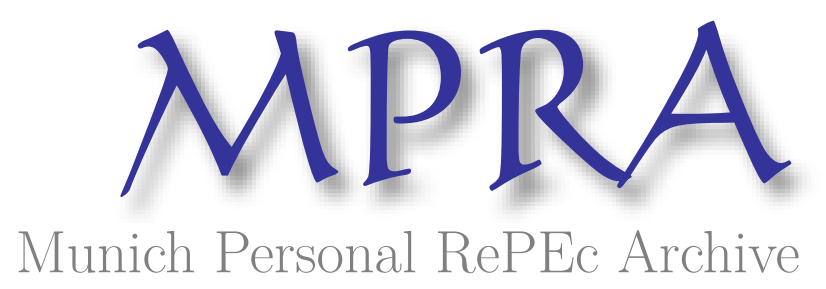

Why Europe looks so much like China: Big government and low income inequalities

Popov, Vladimir

CEMI

28 February 2021

Online at https://mpra.ub.uni-muenchen.de/106326/

MPRA Paper No. 106326, posted 08 Mar 2021 07:42 UTC 


\title{
Why Europe looks so much like China: Big government and low income inequalities
}

\section{Vladimir Popov}

\begin{abstract}
One view in the literature (Popov 2020) is that East Asian model is superior to other models in the Global South, at least in terms of catch-up development and possibly even in innovations beyond the technological frontier. Unlike economic models in Latin America and Sub-Sahara Africa, the East Asian model prioritizes community interests (e.g., that of work collective, neighbourhood, nationstate, and all of humanity) over those of individuals with the possibility of limiting some human rights for the greater benefit of all.

Crucial features of the East Asian economic model include relatively low income and wealth inequalities, strong state institutional capacity (as measured by the murder rate and share of the shadow economy). The origins of the East Asian economic model can be traced to different trajectories of the development of the Global South since the 16th century (Popov, 2009; 2014).

This paper argues that European economic model and East Asian model have a lot in common. After controling for the size of the country and the level of development, it turns out that government consumption as a share of GDP is relatively high in both models, whereas income inequalities are relatively low.
\end{abstract}

Keywords: Varieties of capitalism, economic models, inequalities, size of the government, state institutional capacity, growth rates, catch up development

JEL: H1, D63, O47, P10, P51. 


\section{Why Europe looks so much like China: Big government and low income inequalities}

\section{Vladimir Popov}

Two basic economic models prevail in the Global South: one is the replication of the Western liberal model (e.g., in Latin America, Sub-Saharan Africa, and some former Soviet republics), and the other is sometimes referred to as an 'Asian values' model. These 'Asian values' are understood as the prioritisation of community interests (e.g., work collective, neighbourhood, national state, and all of humanity) over those of individuals with the possibility to limit some human rights for the greater benefit of all. Whereas the Western liberal tradition considers at least some human rights unalienable, in more traditional societies - not only in Asia but also in other parts of the Global South - collectivist solidarity is more entrenched. The core feature of the latter is the statistically measurable indicators of low income and wealth inequalities that helps to promote greater social cohesion and stronger institutional capacity of the state.

It is argued that these features of the Asian model allow to maintain relatively strong and efficient governments and to promote successful catch-up development (Popov, 2009; 2014). This collectivist economic model is found primarily in East Asian countries, but also, to an extent, in the South Asia and Middle East and North African countries. The European economic model, even though it was very different several centuries ago, when it emerged, today is very similar - relatively low inequalities, relatively large and efficient governments (although not very trusted by the public).

\section{Inequalities}

Income and wealth inequalities in Asia and the Middle East and North Africa (MENA) are lower than in Latin America (LA) and Sub-Saharan Africa (SSA). Gini coefficients of income distribution in East Asian countries are usually below 40\%, similar to Europe, and the share of the top $10 \%$ income group in total income ${ }^{1}$ is lower than in the US and many developing countries (India, Russia, South Africa) - fig. 1.

\footnotetext{
${ }^{1}$ This statistic comes from the tax data, not from household surveys that are normally used to study income distribution. Whereas the disadvantage of tax data is that they are not based on representative samples (like household surveys), the
} 
In China, the Gini coefficient of income distribution is above $40 \%$ (even close to $50 \%$ according to the new unified survey for rural and urban regions - fig. 2), but the country is so large that it should be compared with all Europe or at least with the US ${ }^{2}$.

Fig. 1. Share of top income group in total income in selected countries, \%

Top $10 \%$ national income share

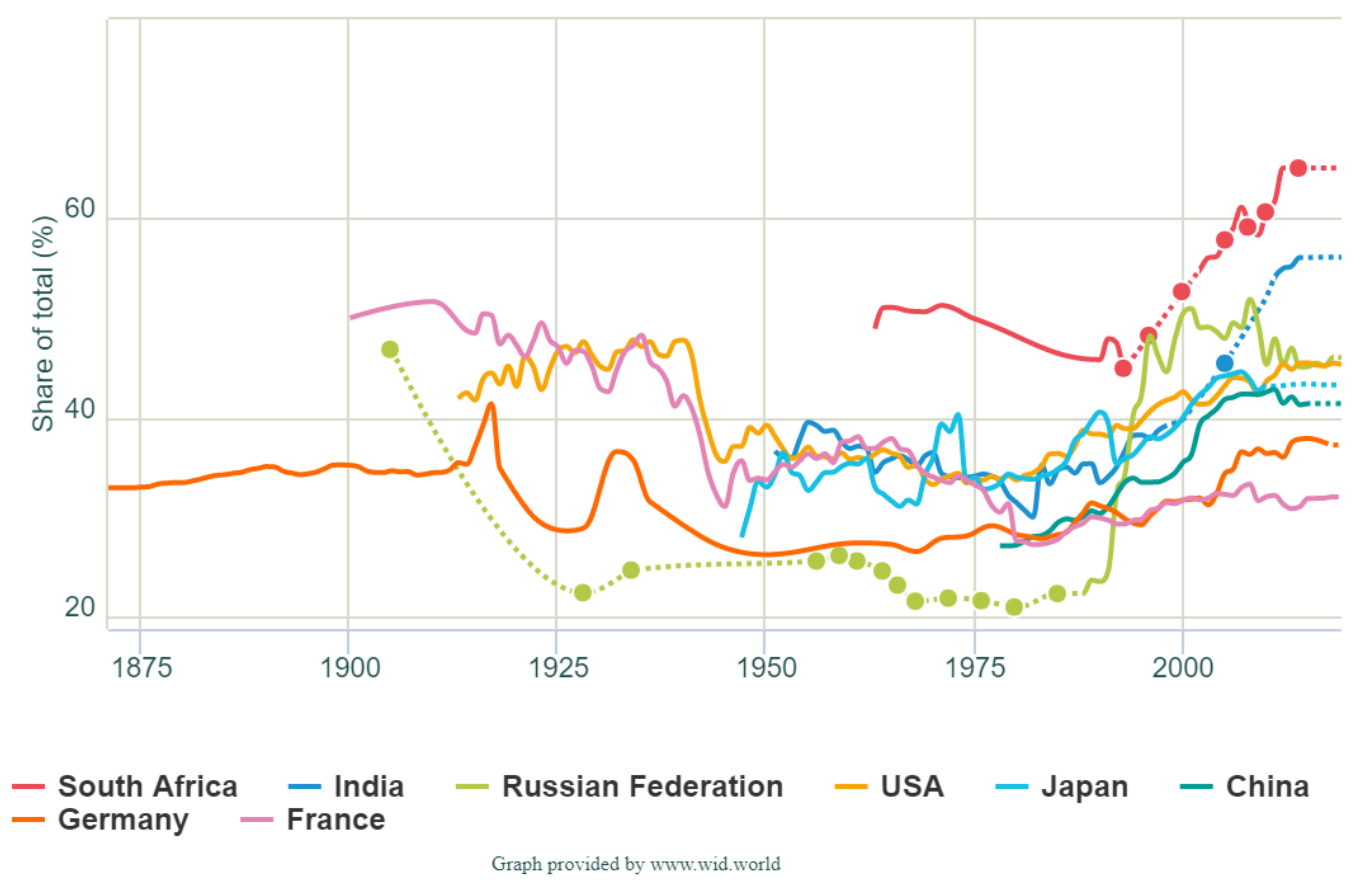

Source: World Inequality Database.

Accounting separately for within- and between-country/province inequalities produces very telling results. In China (29 provinces), the general Gini coefficient of income inequality in the early 2000s was over $40 \%$ with 24 p.p. attributable to between-province disparities. In the US, the Gini coefficient

advantage is that it takes better account of the very rich and very poor groups (that are usually not covered by household surveys).

${ }^{2}$ Three Chinese provinces (Guangdong, Shandong, and Henan) have populations exceeding 95 million. Another several provinces have populations of more than 50 million (i.e., larger than most states). Therefore, China should be compared with multistate regions (e.g., the EU or ASEAN) rather than with particular states. 
was similar (over 40\%), but only 6 p.p. came from disparities in income between the states. In the EU 27 the Gini coefficient around 2005 was roughly $40 \%$ with 23 p.p. coming from between-country inequality. If China can manage to reduce the income gap between its provinces to a level close to the disparities between US states, then general inequality between citizens will fall to quite a low level (Milanovic, 2012), lower than in large European countries.

Fig. 2. Gini coefficient of income distribution in China in 2003-19, \%, new official sample

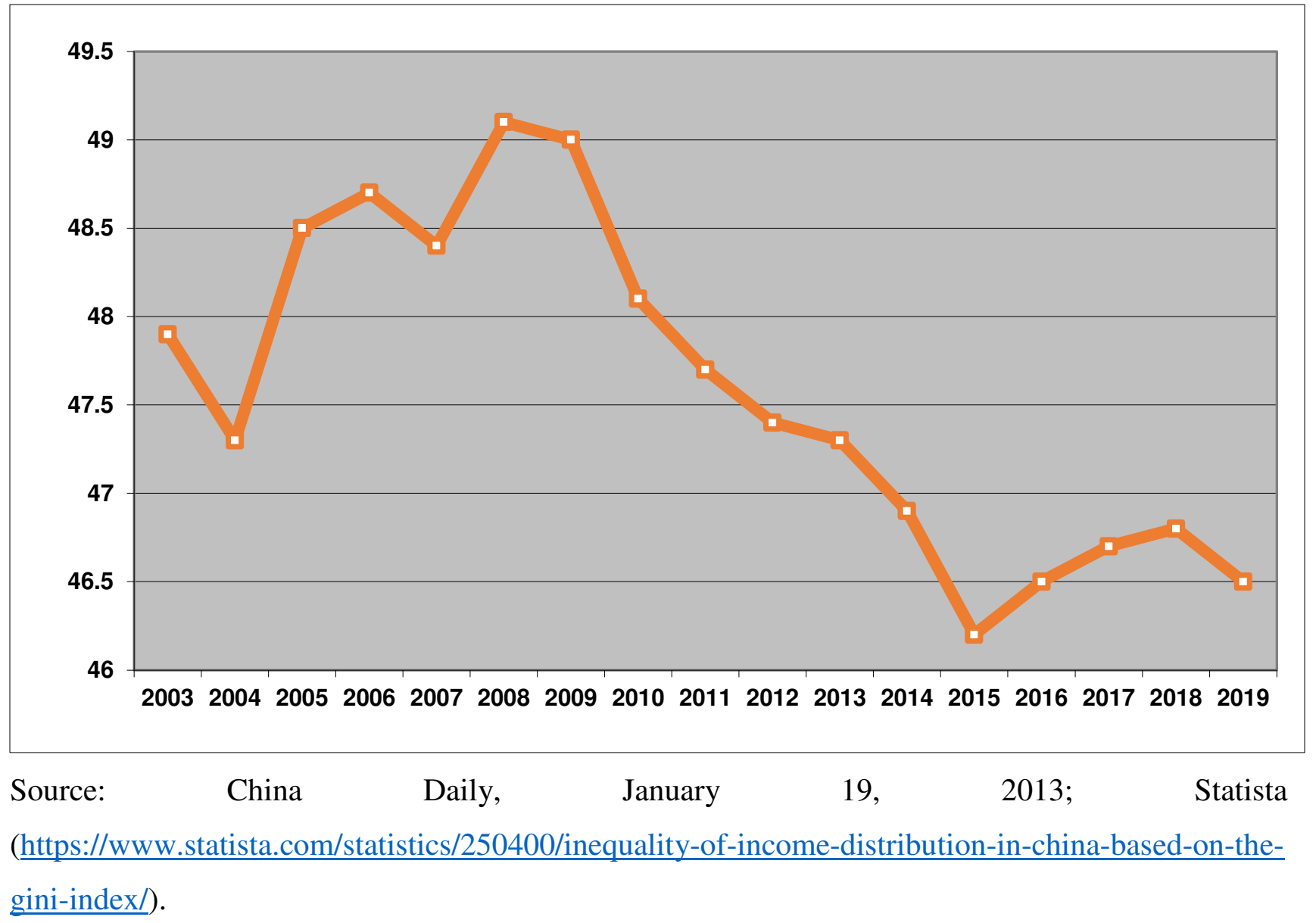

And the wealth inequalities ("accumulated income inequalities") in China appear to be much lower than in other countries. The "billionaire intensity" indicator - the ratio of wealth of billionaires from 
the Forbes list to national income - in 2016 in China was only 6\%, whereas in USA, Germany, France - $10-15 \%$, and in Russia - nearly $30 \%$ (fig. 3).

Fig. 3. Billionaire wealth from Forbes list as a $\%$ of national income in 1990-2016 in major countries

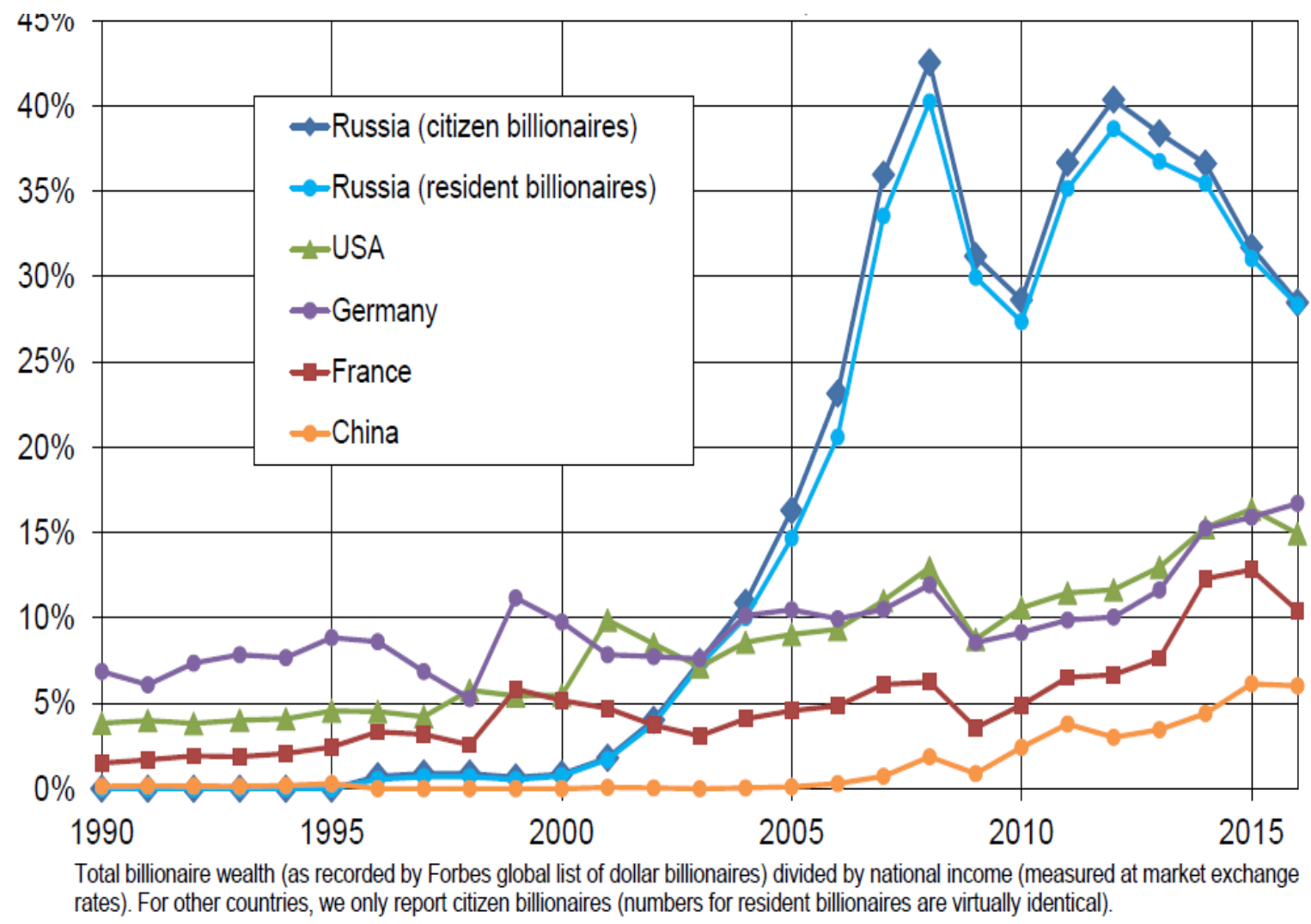

Source: Novokmet, Piketty, Yang, and Zucman (2018).

\section{Institutional capacity}

Lower income and wealth inequalities make societies less polarised and are usually associated with a stronger institutional capacity of the state. The institutional capacity of the state, according to a narrow definition, refers to the government's ability to enforce laws and regulations. While there are many 
subjective indices that are supposed to measure state institutional capacity (e.g., control over corruption, rule of law, government effectiveness indices), they may be biased and different from the objective indicators (Popov, 2011b).

Natural objective measures of state institutional capacity are the murder rate (i.e., non-compliance with the state's monopoly on violence ${ }^{3}$ ) and the shadow economy (i.e., non-compliance with government economic regulations, such as tax payment rules). East Asia and MENA countries are quite different from LA and SSA on both measures: East Asian countries have one of the lowest levels of both indicators in the developing world, comparable to that of developed countries (figs. 4, 5).

In China, for instance, in recent decades there were only 1-2 murders per 100,000 inhabitants compared to 1-2 in Europe and Japan and 5 in the US. Only a few developing countries, mostly in the MENA region, had such low murder rates; these rates are typically higher by an order of magnitude in LA, SSA, and many former Soviet Union states.

It is notable that murder rates in most countries are quite stable over time (fig. 6), but in China the murder rate fell since the 1990 s by nearly $80 \%$ - from 2.3 in 1995 to 0.5 in 2018 per 100,000 inhabitants (fig. 7).

The same pattern applies to the shadow economy: it constitutes less than 17\% of Chinese GDP, lower than in Belgium, Portugal, and Spain. In developing countries, the proportion is typically around $40 \%$, sometimes even greater than $60 \%$ (fig. 8). Only a few developing countries have such a low shadoweconomy share, in particular Vietnam and several MENA countries (e.g., Iran, Jordan, Saudi Arabia, and Syria) - (Popov, 2011a).

\footnotetext{
${ }^{3}$ Crimes are registered differently in different countries; higher crime rates in developed countries seem to be the result of more accurate crime records. But grave crimes, such as murder, appear to be recorded quite accurately even in developing countries, so international comparisons of murder rates are warranted.
} 
Fig. 4: Murder rates in countries with more than 15 murders per 100,000 inhabitants in 2008

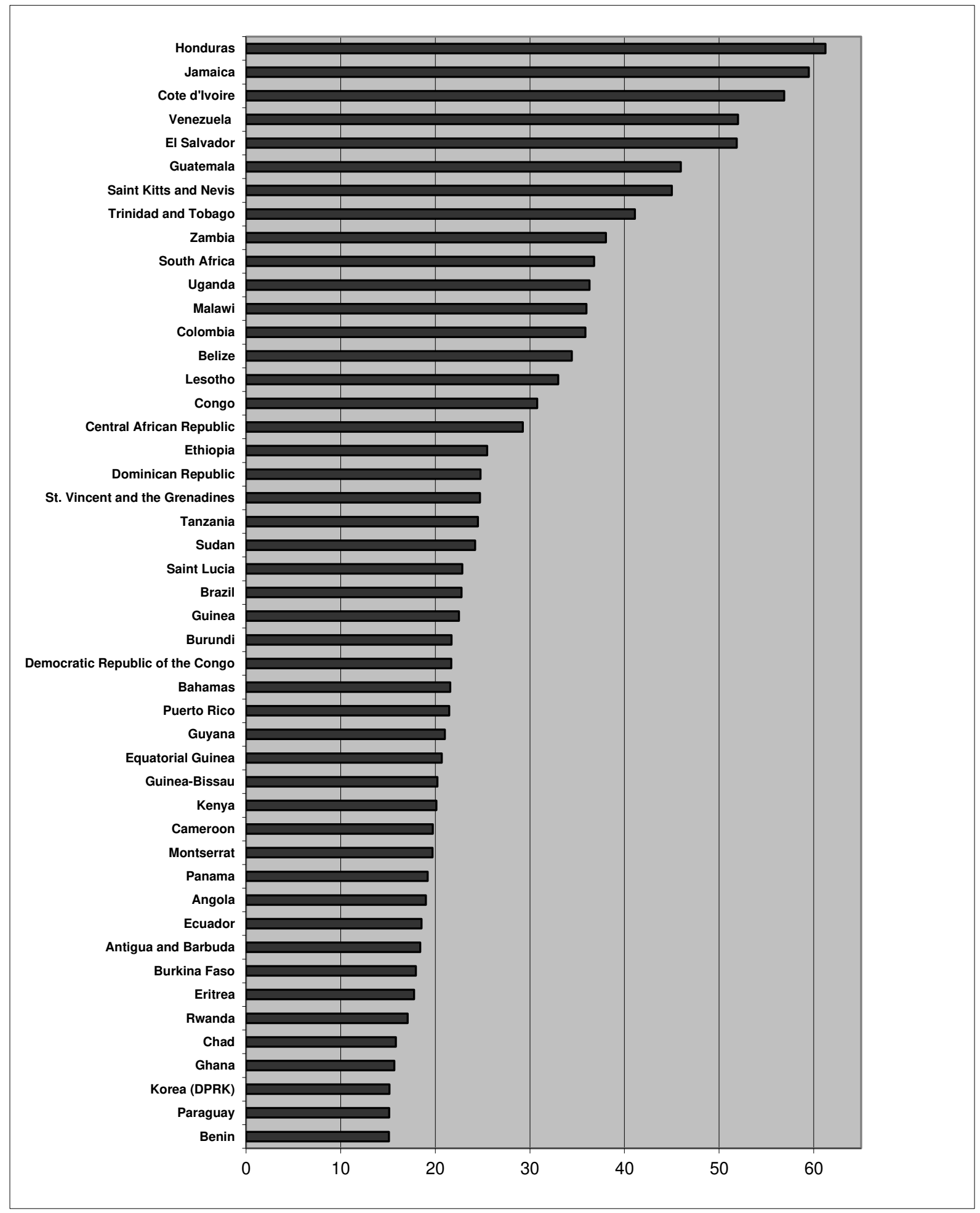

Source: WHO. 
Fig. 5: Murder rates in countries with less than 1.5 murders per 100,000 inhabitants in 2008

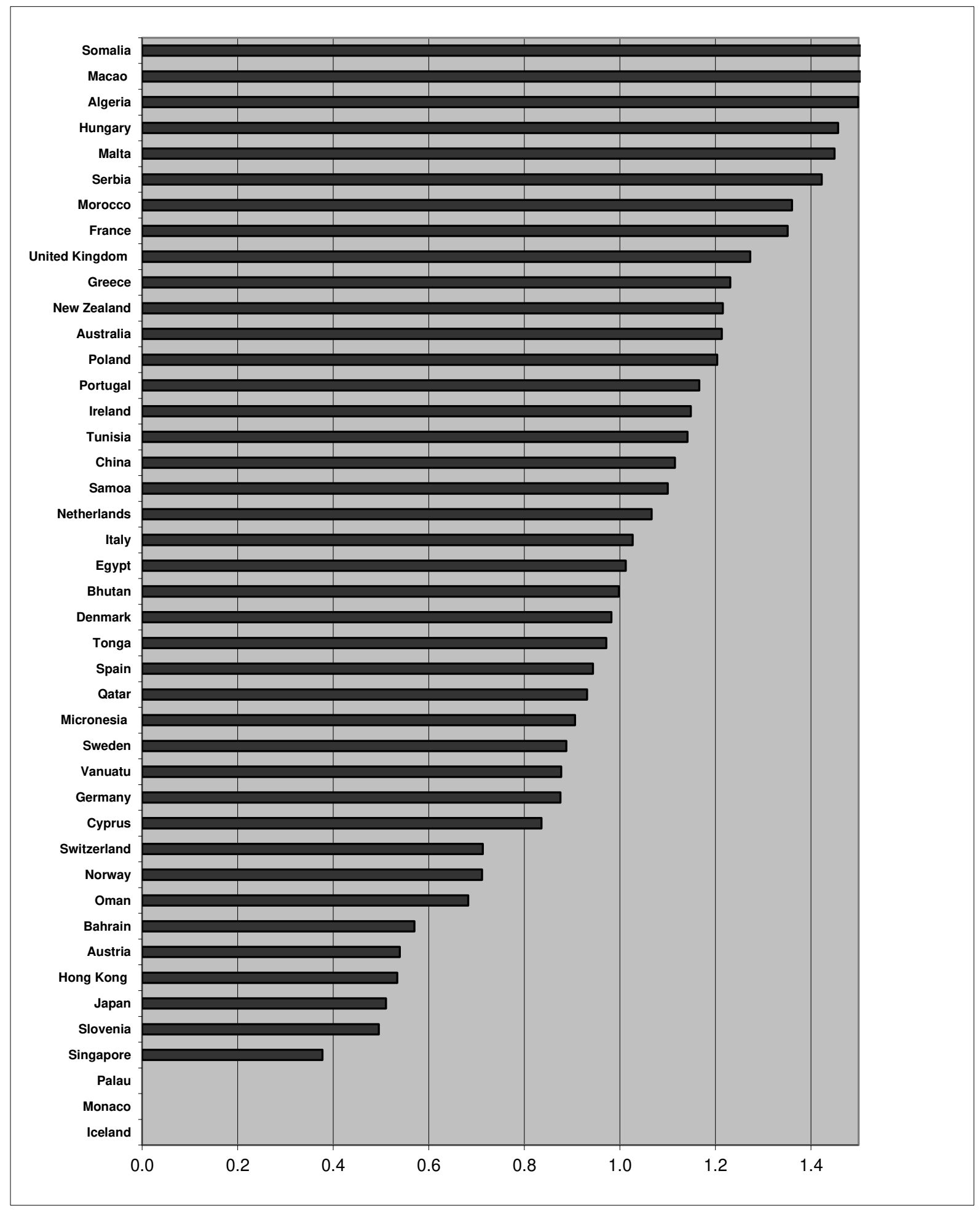

Source: WHO. 
Fig. 6. Average murder rates in 1960-2013 by decades, per 100,000 inhabitants, log scale (countries for which data are available for 3 and more decades)

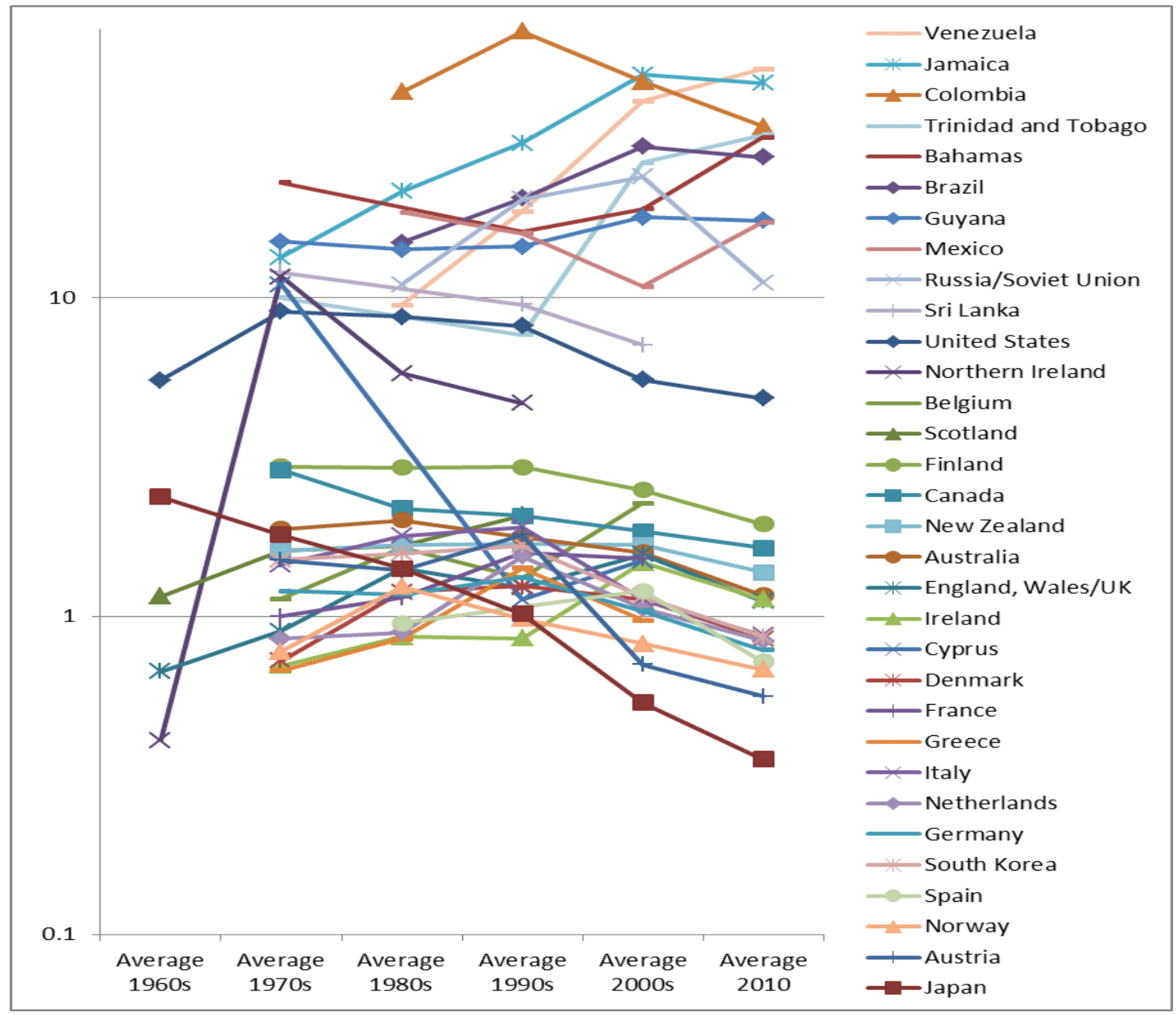

Source: Wikipedia. List of countries by intentional homicide rate by decade (https://en.wikipedia.org/wiki/List_of_countries_by_intentional_homicide_rate_by_decade).

Data are taken from different sources (mostly national data provided to WHO) and sometimes are not strictly comparable. 
Fig. 7. Murder rate in China per 100,0000 inhabitants

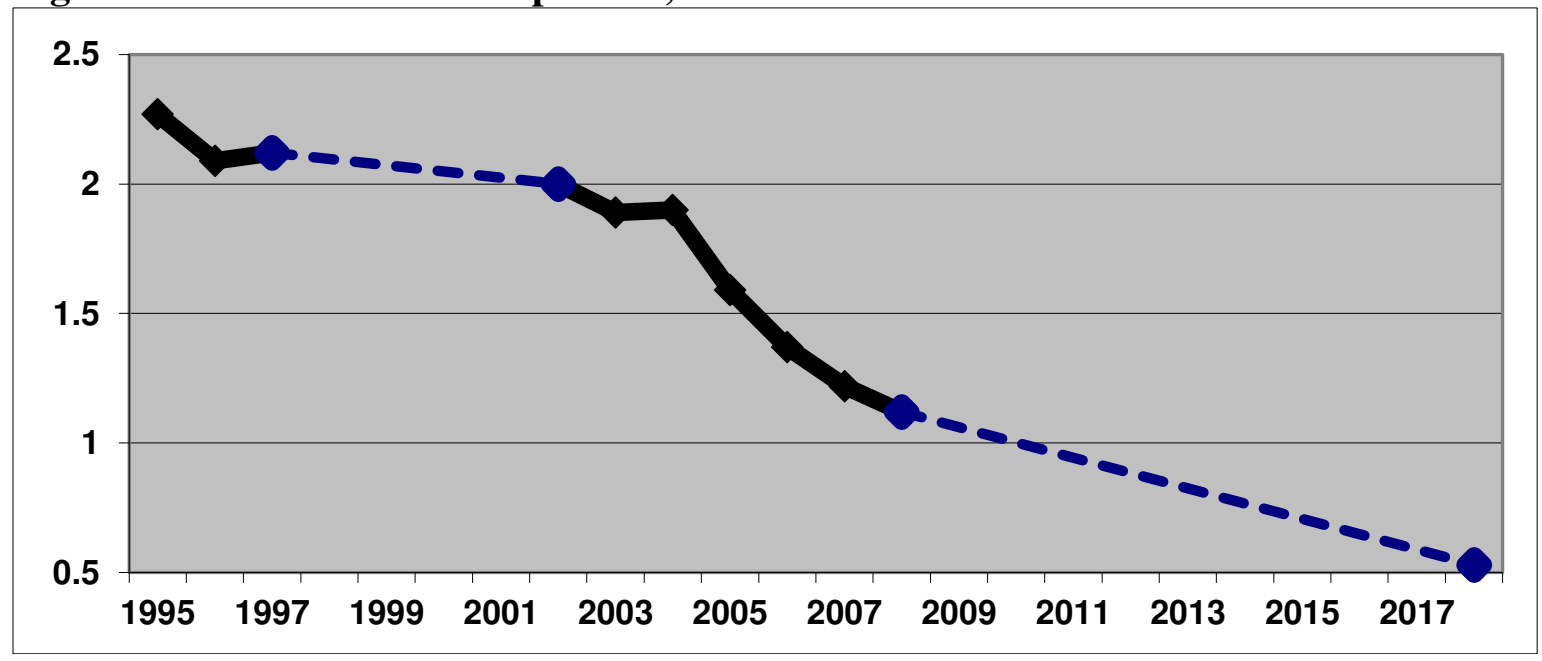

Source: Wikipedia. List of countries by intentional homicide rate (https://en.wikipedia.org/wiki/List_of_countries_by_intentional_homicide_rate); List of countries by intentional homicide rate by decade (https://en.wikipedia.org/wiki/List_of_countries_by_intentional_homicide_rate_by_decade).

Fig. 8. Share of shadow economy in GDP in $2005(\%)$ and murder rate per 100,000 inhabitants in 2002

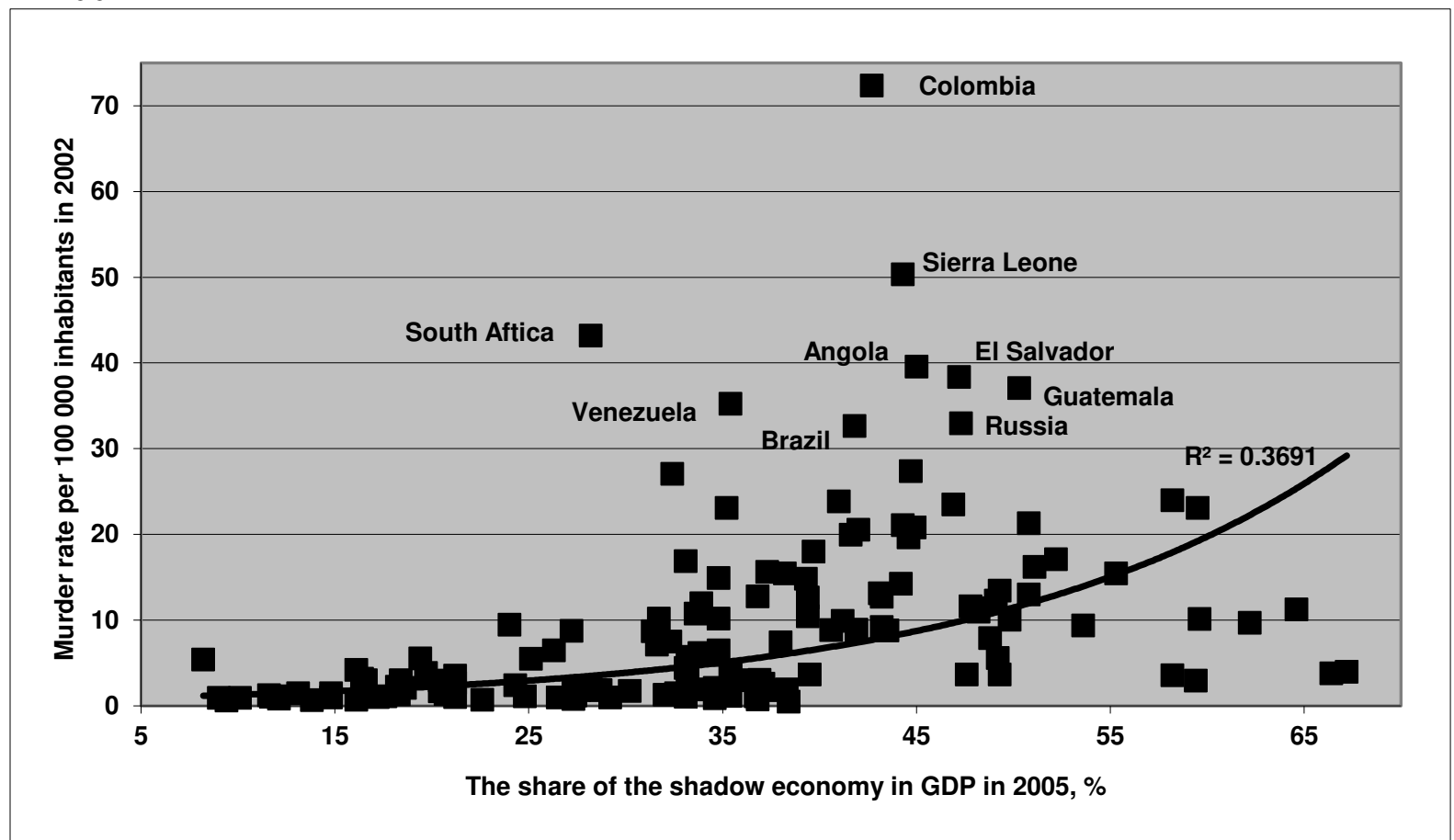

Source: WHO; Schneider, 2007. Measures of the shadow economy are derived from divergence between output dynamics and electricity consumption, demand for real cash balances, etc.). 
Needless to say that growth rates of productivity and per capita GDP depend on the institutional capacity of the state (Popov, 2015)4, so countries with the strongest institutional capacity, ceteris paribus, have better chances to become growth miracles. So far only 5 countries/territories form the Global South - Hong Kong, Japan, Singapore, South Korea, Taiwan - managed to join the rich country club due to their high economic growth rates. ${ }^{5}$ In recent decades Southeast Asia and China were catching up with the developed countries as well. ${ }^{6}$

\section{Inequality, state capacity, trust in the government and patriotism}

Low income inequality is generally tied to strong institutional capacity (e.g., low murder rate and low shadow economy), but to be more nuanced, it may make sense to distinguish between three groups of countries (Popov, 2020) - see fig. 9:

\footnotetext{
${ }^{4}$ The cross-country regression equations of growth rates of GDP per capita in 1960-2013 on the objective indicators of the state institutional capacity (shadow economy and murder rate) are reported below (from Popov, 2015):

$\boldsymbol{y}=-0.0003 * * *$ Ycap75 $-0.03 *$ MURDERS $-0.14 * * * S H A D O W+5.32 * * *$

$\begin{array}{llll}(-4.95) & (\mathbf{1}) 67) & (-4.82) & (8.55)\end{array}$

$\mathrm{N}=80, \mathrm{R}^{2}=0.38$, robust standard errors, $\mathrm{T}$-statistics in brackets below;

$\boldsymbol{y}=0.003 * * *$ POPDENS $-0.0002 * * *$ Ycap75 -0.023 MURDERS $-0.067 * * *$ SHADOW $+5.04 * * *$

(4.08) (-4.33) (-1.62) $\quad(-4.40) \quad(7.67)$

$\mathrm{N}=80, \mathrm{R}^{2}=0.40$, robust standard errors, $\mathrm{T}$-statistics in brackets below, where

$\boldsymbol{y}$-annual average growth rates of per capita GDP in 1960-2013,\%,

POPDENS - number of residents per 1 square $\mathrm{km}$ in 2000 ,

Ycap75 - per capita PPP GDP in 1975 in dollars,

MURDERS - number of murders per 100,000 inhabitants in 2002,

SHADOW - share of shadow economy in GDP in 2005, \%.
}

Data on growth, population density and PPP GDP per capita are from WDI, data on murders are from WHO, data on shadow economy are from Schneider, 2007 (measures of the shadow economy are derived from divergence between output dynamics and electricity consumption, demand for real cash balances, etc.).

5 Some developing countries became rich not due to rapid economic growth, but because of improved terms of their external trade - increased relative prices for their export goods. The best known example is oil exporting states of the Persian Gulf: with the exception of Oman, these countries did not enjoy high growth rates of physical output, but their per capita income approached the level of developed countries due to increase in oil prices since 1973.

${ }^{6}$ In 1920s-1970s, the USSR and East European countries were catching up with the developed countries, but later they slowed down considerably and, in the 1990s, experienced transformational recession. In 1950-2020, high average growth rates (over $3 \%$ of per capita GDP annual growth) in developing world, in addition to East Asia, were observed in Botswana, Israel, and Oman. 
Fig. 9. Gini coefficients of income distribution, murder rate, and shadow economy
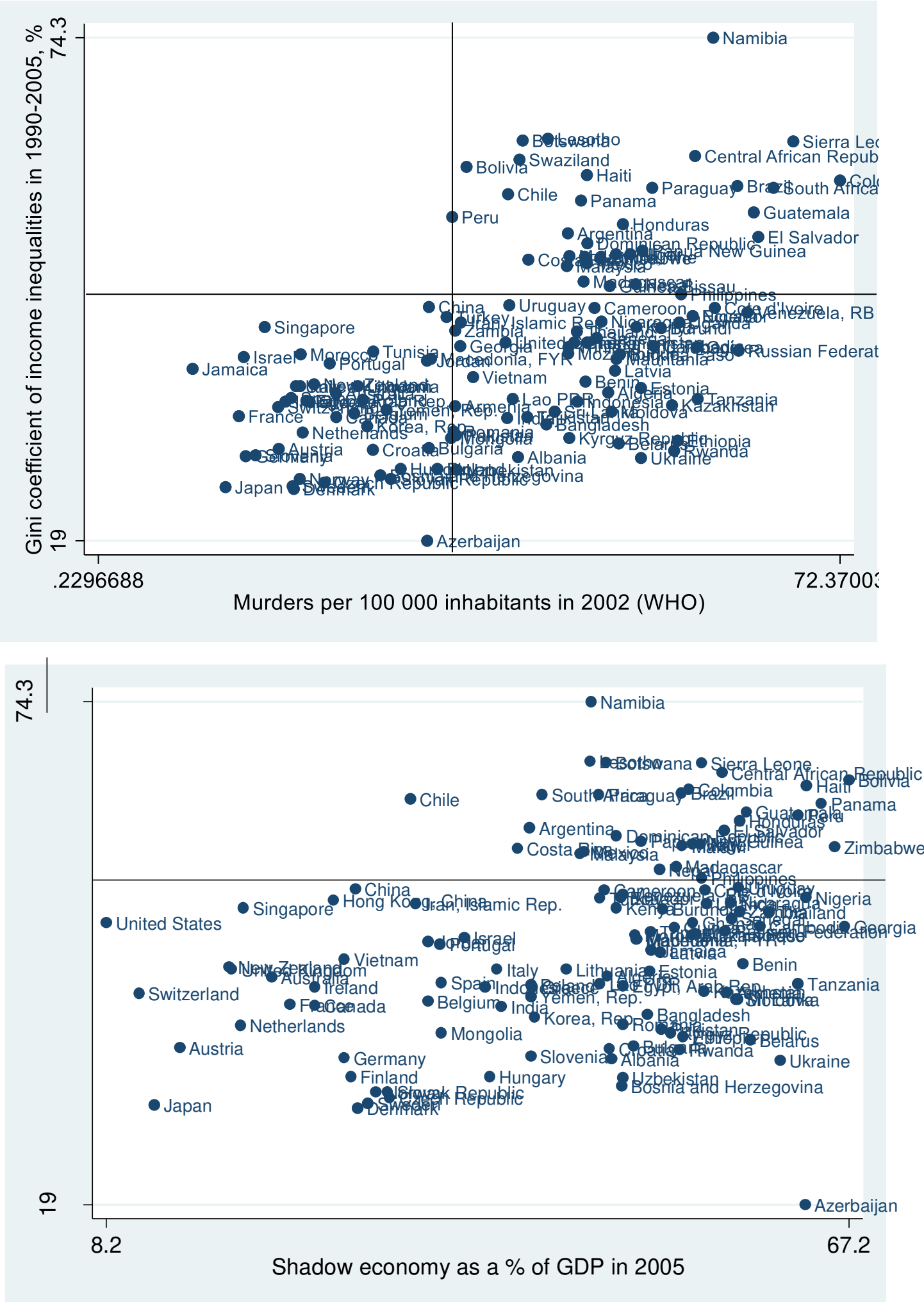

Source: World Development Indicators database; Schneider, F. (2007). 
- low inequality and strong institutions (e.g., developed countries; some East Asian and MENA states);

- relatively low inequality and poor institutions (e.g., former socialist countries and some MENA and East Asian states);

- $\quad$ and high inequality and poor institutions (e.g., LA and SSA).

Similar (but not identical) results can be observed by plotting several subjective measures of solidarity from the World Value Survey - trust in government and willingness to fight for one's own country ${ }^{7}$ (fig. 10) - against the murder rate, an objective indicator of institutional strength. Here we can distinguish between four groups of countries (fig. 11):

Fig. 10: Trust-in-government index and patriotism index, $\log$ scale

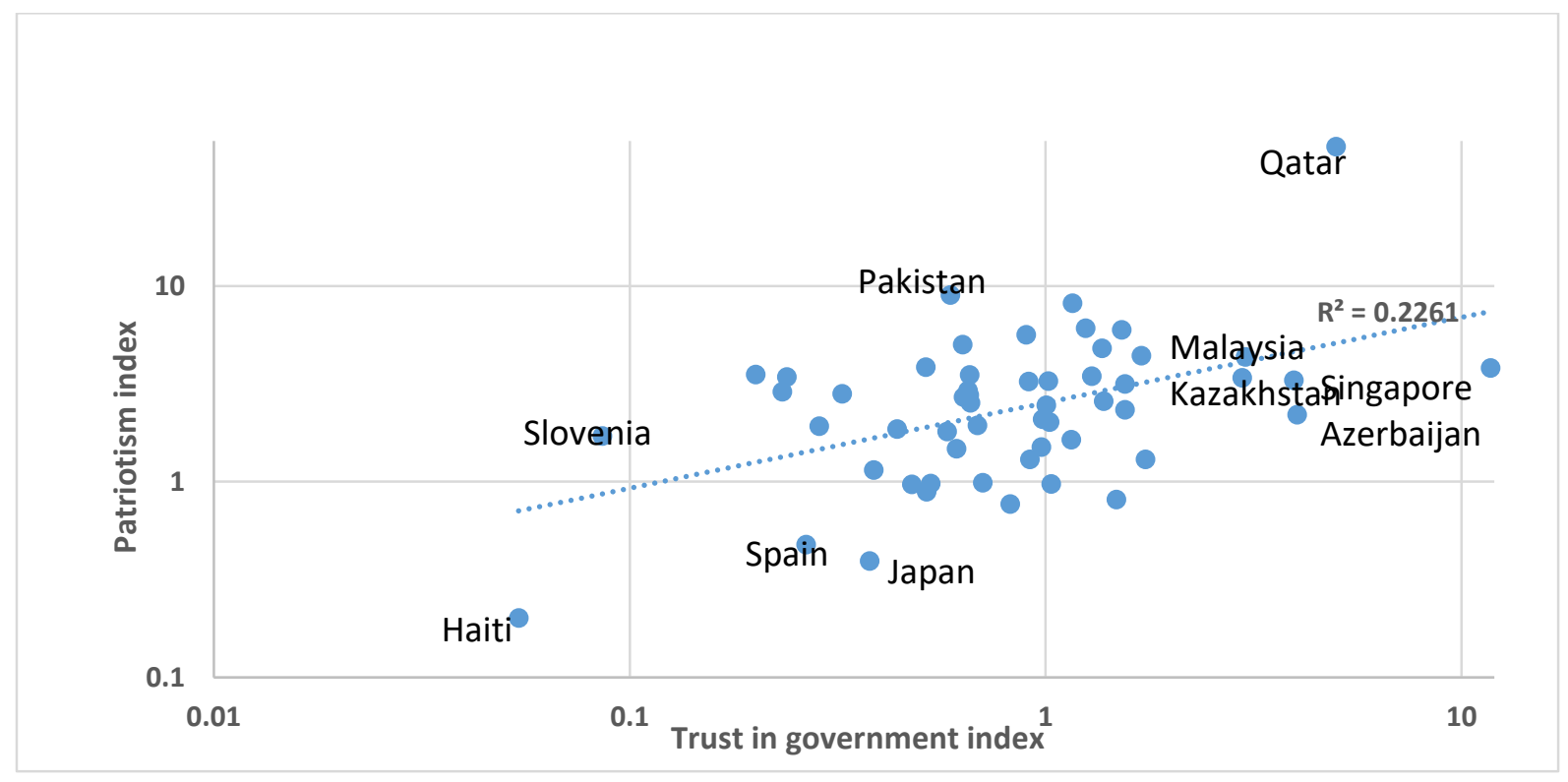

Source: World Value Survey.

\footnotetext{
7 The patriotism index and trust-in-government index are computed as the ratio of positive answers to negative answers in Round 6 (2010-14) of the World Value Survey.

Question about patriotism (V66): Of course, we all hope that there will not be another war, but if it were to come to that, would you be willing to fight for your country?

Question about trust in government (V115): How much confidence you have in the government (in your nation's capital): is it a great deal of confidence, quite a lot of confidence, not very much confidence or none at all?
} 
Fig. 11: Patriotism index, trust in government, and murder rate
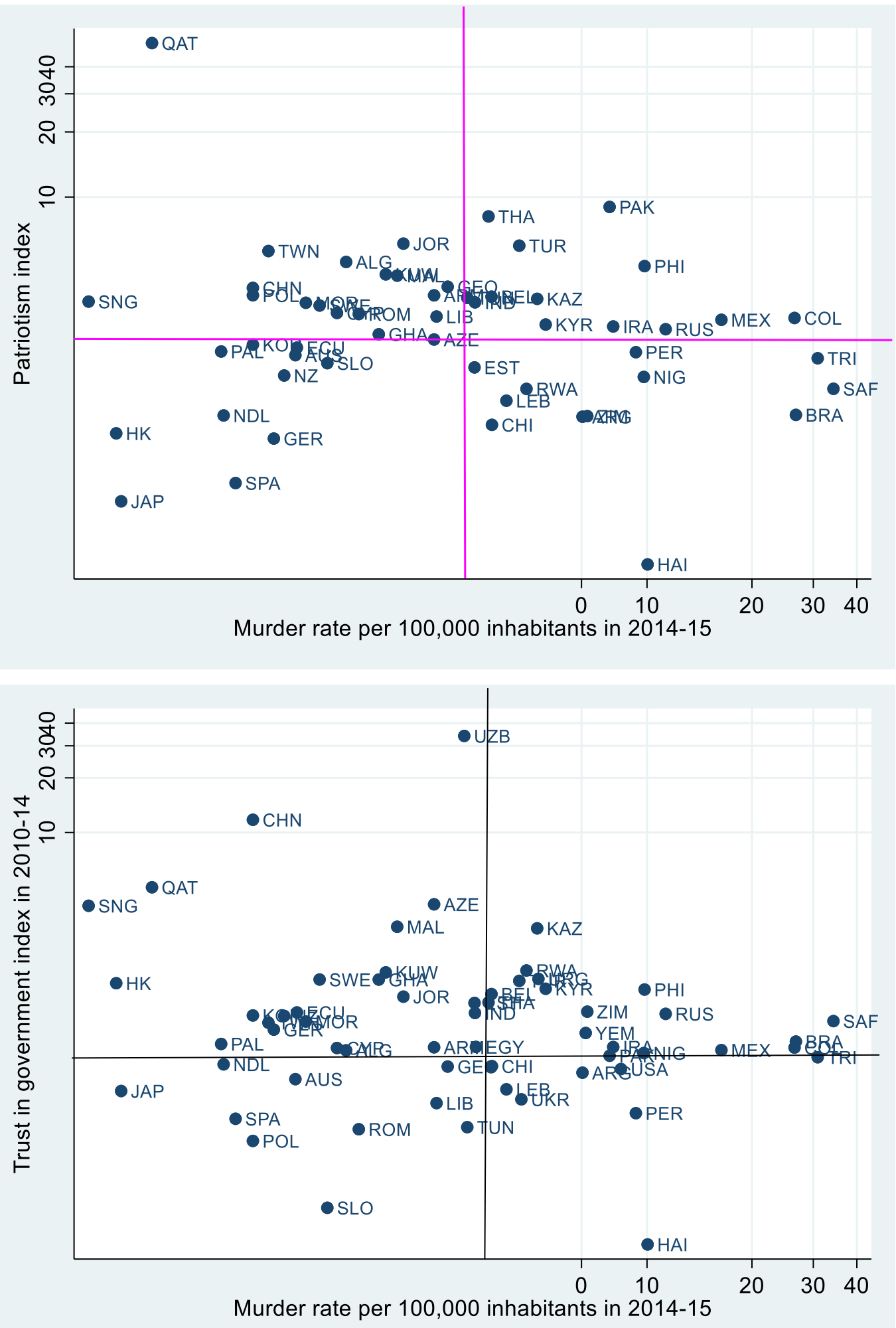

Source: World Values Survey. 
- East Asian and MENA countries have generally low murder rates and higher patriotism and trust in the government;

- developed countries have low murder rates and low trust and patriotism;

- many LA and SSA countries have lower indicators of trust and patriotism and high murder rates;

- many states of the former Soviet Union (e.g., Belarus, Kazakhstan, Kyrgyzstan, and Russia) have high murder rates along with high trust in the government and patriotism.

It can be hypothesised that higher trust in governmental institutions and stronger patriotism (i.e., willingness to fight for one's own country) can build social cohesion and solidarity in difficult times, even if objective measures of institutional strength (e.g., murder rate and the shadow economy) are not that impressive. Conversely, strong institutions may not be enough to respond effectively to crises if social solidarity is weak. This trend may explain why, in advanced countries struck by the coronavirus, quarantine and isolation measures were less strict and enacted after a delay compared to East Asian and MENA countries, leading to much higher infection and death rates in the former (Popov, 2020).

A related measure of social cohesion is the Inglehart-Welzel cultural map of the world (fig. 12) that is based on questions of the World Value Survey.

Patriotism and trust in the government are regarded in this classification as the traditional values that "emphasize the importance of religion, parent-child ties, deference to authority, absolute standards and traditional family values. People who embrace these values also reject divorce, abortion, euthanasia and suicide. Societies that embrace these values have high levels of national pride and a nationalistic outlook". Self-expression values, as opposed to survival values, "give high priority to subjective well-being, self-expression and quality of life" (Inglehart, Welzel, 2013).

Self-expression naturally becomes more important with economic progress - growth of per capita income, so that developed countries are more oriented towards self-expression and less to survival than developing countries. It is interesting though that on a secular- traditional scale (vertical axis of fig. 12) there are clearly two groups of developing countries - East Asia and former communist countries are quite "modern" and secular, whereas Latin America and Sub-Sahara Africa are more 
traditional (Middle East and North Africa and South Asia are in between). It could be hypothesized that East Asia and former communist countries maintain collectivist values and low inequalities in a "modern" rather than in a "traditional" way. This modern way implies the greater reliance on the individual responsibility enforced by the power of the government (state capacity), not so much on family and the community.

Fig. 12. Inglehart-Welzel cultural map of the world

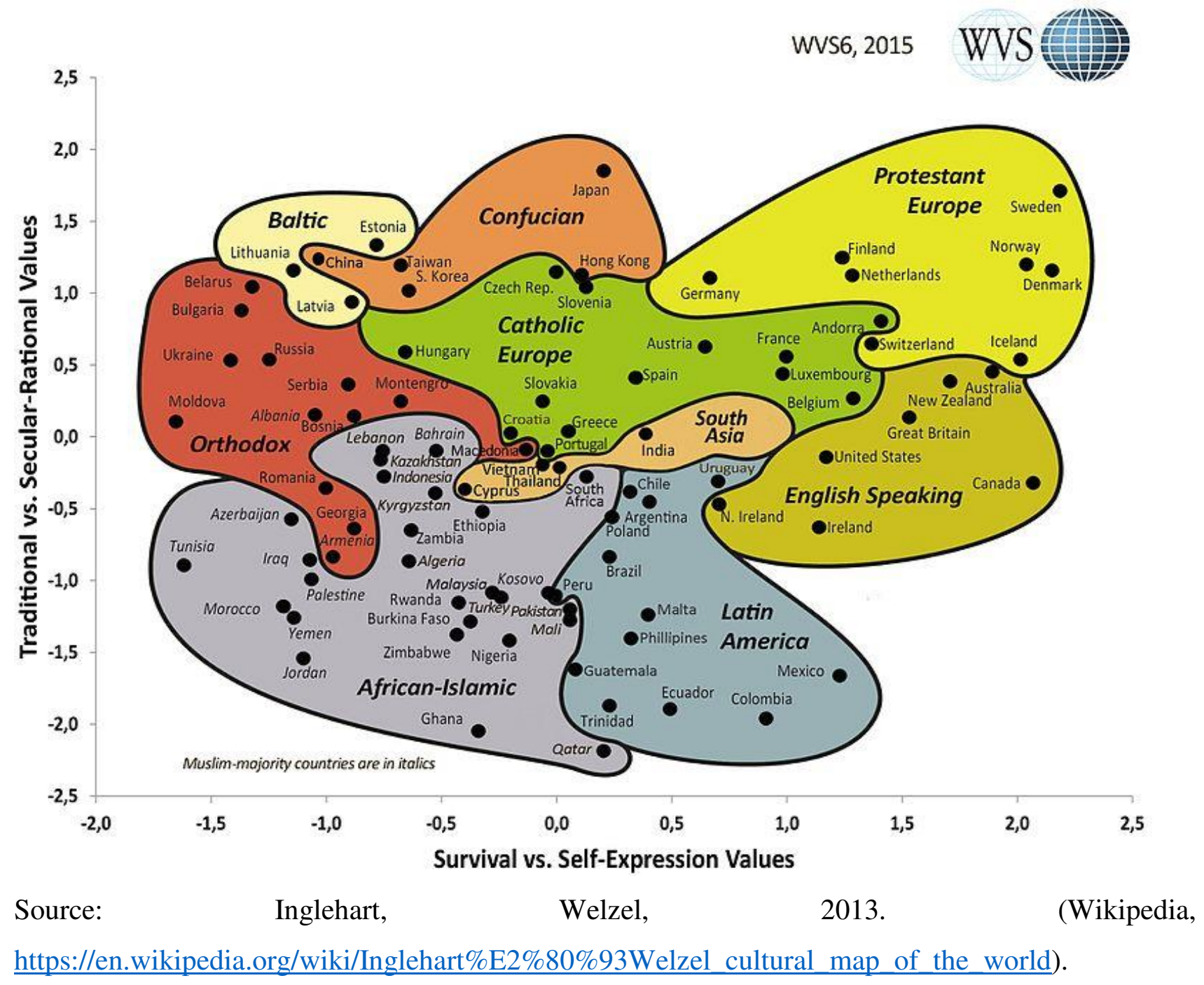




\section{Inequality and government size}

The raw data on income inequalities and the share of government consumption ${ }^{8}$ in GDP (fig. 13) show weak negative relationship - the higher the government consumption, the lower is the Gini coefficient of income inequalities. This negative relation, however, is driven by the differences between rich and poor countries - with the growth of per capita income the share of government consumption increases, whereas the income inequalities decline. As the per capita income increases, the government provides more and more public goods (health care, education, infrastructure) and expands social programs that mitigate income inequalities. To eliminate this factor, one has to control for the level of development (per capita GDP).

Fig. 13. Gini coefficient of income inequalities and the share of government consumption in GDP, average for 2016-19 and 2011-19, \%

2016-19

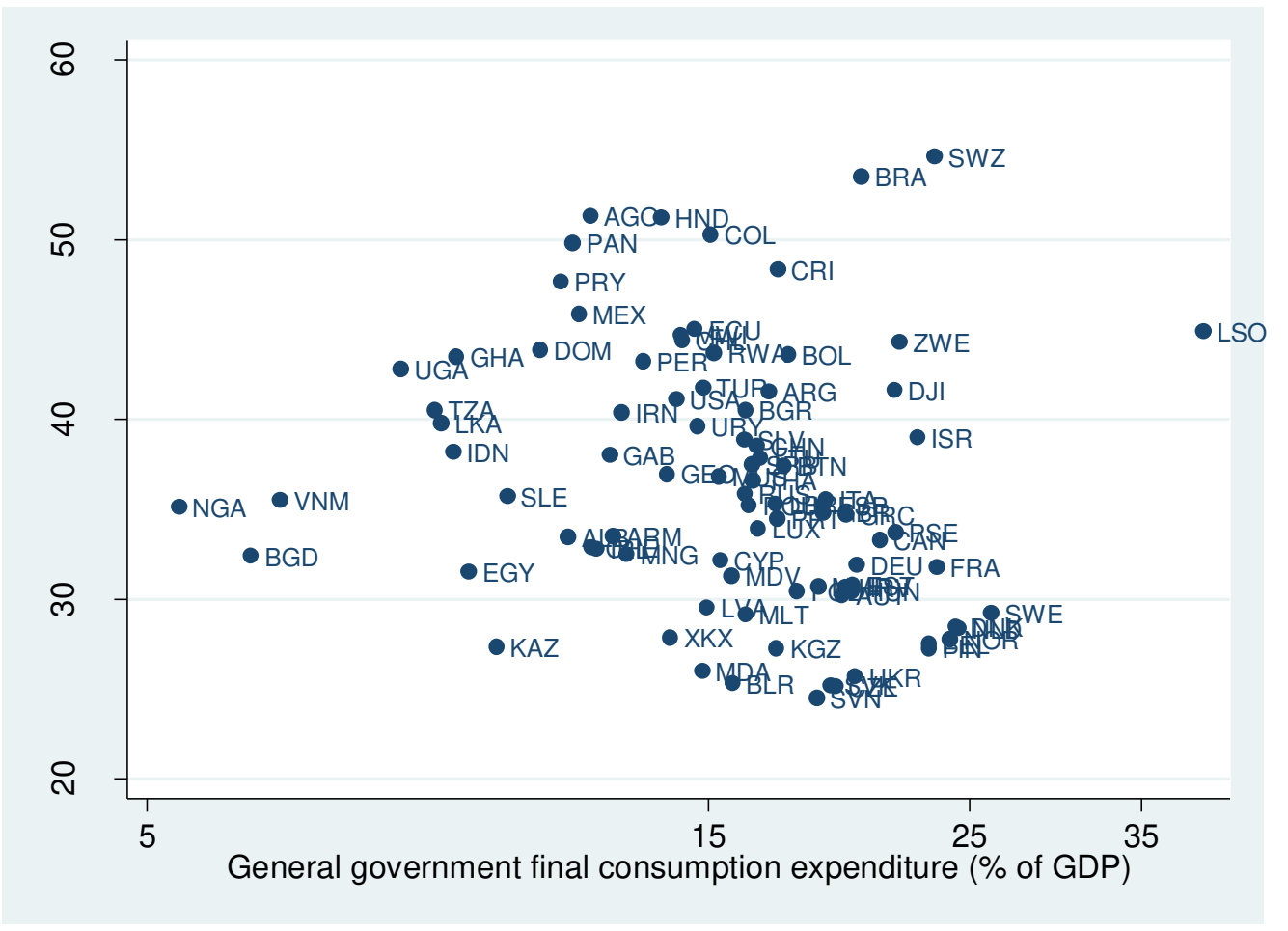

\footnotetext{
${ }^{8}$ The comparable data on all countries are available only for the government consumption (final government purchases of goods and services). Total government expenditure is equal to the sum of government consumption and government transfers (pensions, allowances, etc.).
} 
2011-19

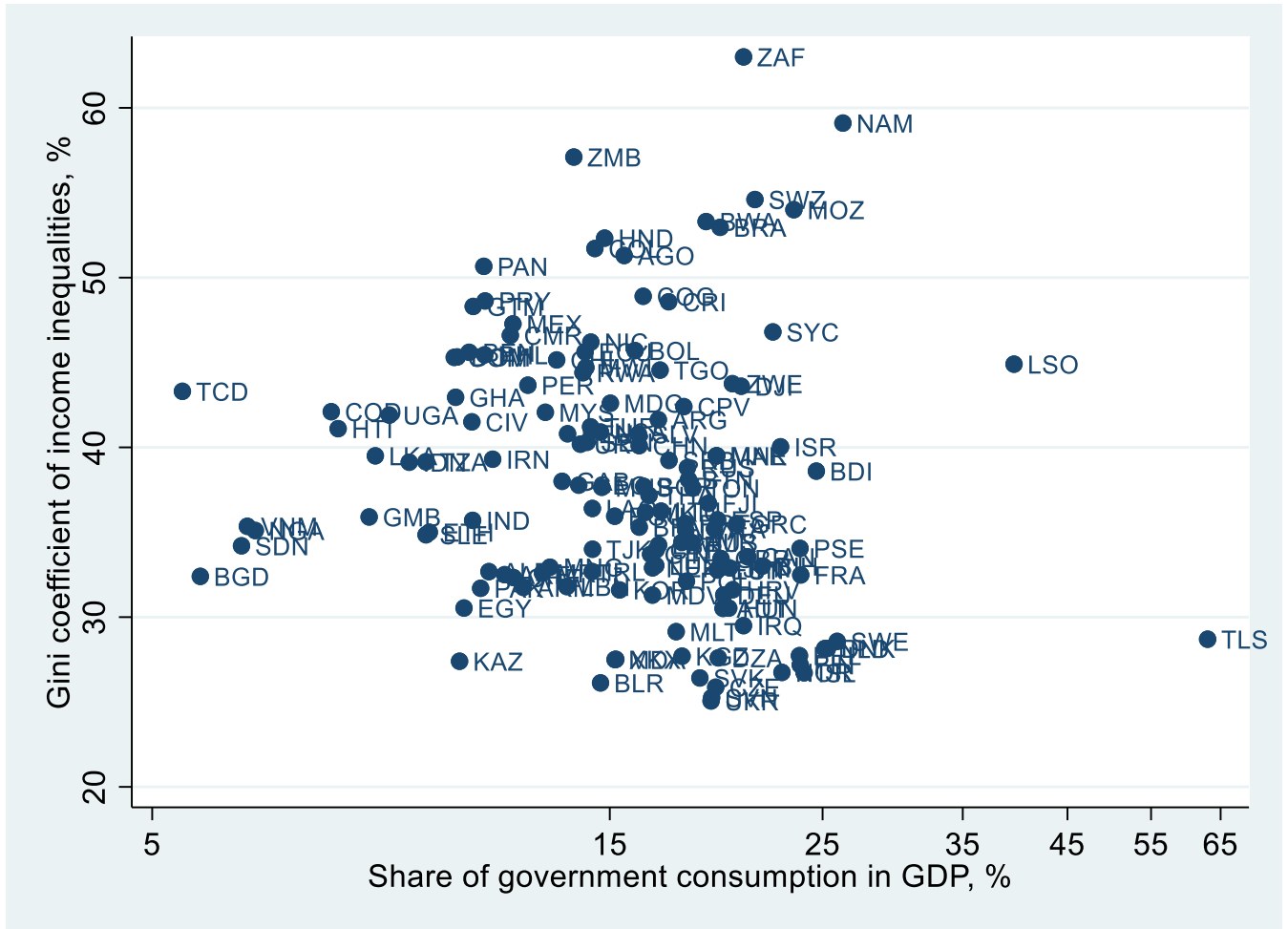

Source: WDI.

Besides, larger countries generally have smaller governments as they can enjoy economies of scale (one currency, one border control and custom office, etc.) and they are less vulnerable to the shocks from the world market. Rodrik (1998) shows that more open economies have bigger governments and this holds for developed and developing countries. Small countries are naturally more open (higher share of external trade and capital flows in GDP), so other things being equal, smaller states have bigger governments. And, as was already mentioned, inequalities in larger countries are likely to be higher because of the uneven development of various regions of the large country.

Regressions of Gini coefficients and government consumption on PPP GDP and PPP GDP per capita are reported below: 
Averages for the period 2016-19 (88 countries):

$$
\text { GINIcoef }=-0.00015 * * * \text { GDPcap }+\mathbf{3 . 2 2} * 10 \mathrm{e}^{-13} * \mathbf{G D P}+39.7 * * * \text {, robust }
$$

Number of obs. $=88, \quad$ R-squared $=0.1710$, robust standard errors, $\mathrm{T}$-statistics in brackets below;

$$
\text { GOVcons }=16.0-0.77 * * \ln G D P+2.1 * * * \operatorname{lnGDPcap},
$$

Number of obs. $=88, \quad$ R-squared $=0.1311$, robust standard errors, $\mathrm{T}$-statistics in brackets below; where

GINIcoef - average Gini coefficient of income distribution in 2016-19, \%,

GOVcons - average final general government consumption as a \% of GDP, in 2016-19, \%, GDP - average PPP GDP in 2016-19 in 2017 constant international dollars, GDPcap - average PPP GDP per capita in 2016-19 in 2017 constant international dollars.

Averages for the period 2011-19 (144-217 countries):

GINIcoef $=-2.5 * * * \operatorname{lnGDPcap}+2.4 * 10 \mathrm{e}^{-13 *}$ GDP $+60.8 * * *$, robust

Number of obs. $=144, \quad \mathrm{R}$-squared $=0.1206$, robust standard errors, $\mathrm{T}$-statistics in brackets below;

GOVcons $=-0.75^{* * *} \operatorname{lnGDP}+1.2 * * * \ln$ GDPcap $+24.7^{* * *}$,

Number of obs. $=217$, R-squared $=0.0929$, robust standard errors, T-statistics in brackets below;

where

GINIcoef - average Gini coefficient of income distribution in 2011-19, \%, 
GOVcons - average final general government consumption as a \% of GDP, in 2011-19, \%, GDP - average PPP GDP in 2011-19 in 2017 constant international dollars,

GDPcap - average PPP GDP per capita in 2011-19 in 2017 constant international dollars.

The residuals from these regressions show the deviation of the relative share of government consumption in GDP and Gini coefficients of income inequalities from the predicted levels (given the size of the country and the level of development). The simplified general picture is described by the scheme below (see Appendix).

Scheme. Classification of economic models - deviation of income inequalities and the size of the government from predicted levels

\begin{tabular}{|c|c|c|}
\hline $\begin{array}{l}\text { INEQUALITY } \\
\text { SIZE OF THE } \\
\text { GOVERNMENT }\end{array}$ & LOW & HIGH \\
\hline BIG & $\begin{array}{l}=\text { Big government } \\
=\text { High state capacity } \\
=\text { Low inequality } \\
\text { EAST ASIA, EUROPE }\end{array}$ & $\begin{array}{l}\text { = Big government } \\
=\text { Low state capacity } \\
=\text { High inequality } \\
\text { LATIN AMERICA, SUB- } \\
\text { SAHARA AFRICA ( Argentina, } \\
\text { Botswana, Brazil, Djibout, } \\
\text { Eswatini, Mozambique, } \\
\text { Namibia, Seychelles, South } \\
\text { Africa, Togo, Zimbabwe), } \\
\text { RUSSIA }\end{array}$ \\
\hline SMALL & $\begin{array}{l}\text { = Small government } \\
\text { = Low state capacity } \\
\text { = Low inequality } \\
\text { FORMER USSR and socialist countries } \\
\text { (Albania, Kosovo, Lao PDR, North } \\
\text { Macedonia, Mongolia, Vietnam,) } \\
\text { + South Asia and MENA ( Bangladesh, } \\
\text { India, Mauritania, Morocco, Pakistan, } \\
\text { Sudan, UAE) }\end{array}$ & $\begin{array}{l}=\text { Small government } \\
=\text { Low state capacity } \\
=\text { High inequality } \\
\text { LATIN AMERICA, SUB- } \\
\text { SAHARA AFRICA, USA }\end{array}$ \\
\hline
\end{tabular}


There are four group of countries (scheme):

- with relatively low inequalities and big governments - East Asia and Europe;

- with relatively high inequalities and small governments - Latin America and Sub-Sahara Africa, USA;

- with relatively low inequalities and small governments (former USSR, South Asia and MENA);

- with relatively high inequality and big government (LA, SSA, Russia).

More detailed data are in the charts below and in the Appendix.

For the period of 2016-19 relatively low income inequalities and high government consumption group includes European countries (Austria, Belgium, Croatia, Czech Republic, Denmark, Estonia, Finland, France, Germany, Greece, Hungary, the Netherlands, Norway, Poland, Portugal, Slovak Republic, Slovenia, Sweden, Ukraine); East Asia (China, Myanmar, Thailand). Besides, there are Bhutan, Liberia, Kyrgyz Republic, West Bank and Gaza that do not exactly fit into the primitive model (figs. 14-15; Appendix, table1). 
Fig. 14. Excess government consumption as a \% of GDP and deviation of Gini coefficient of income distribution, p.p. (2016-19 data)

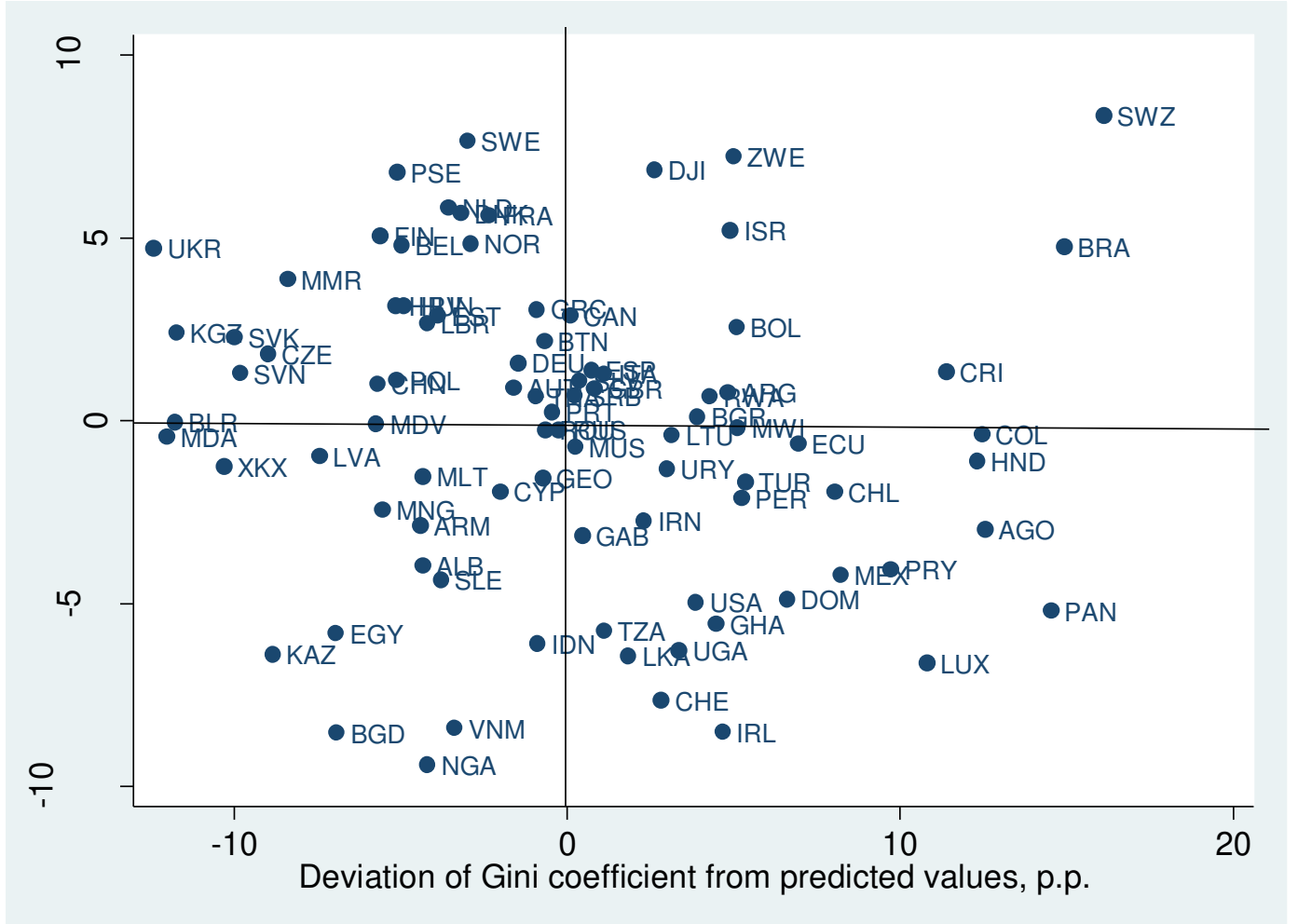

Source: WDI (see Appendix).

Relatively high income inequalities and low share of the government consumption in GDP in 2016-19 are observed in Sub-Sahara Africa countries (Angola, Gabon, Ghana, Malawi, Mauritius, Tanzania, Uganda); Latin American countries (Chile, Colombia, Dominican Republic, Ecuador, Honduras, Mexico, Panama, Paraguay, Peru) and the United States; and several "outsiders' (Iran. Ireland, Lithuania, Luxembourg, Sri Lanka, Switzerland, Turkey). 
Fig. 15. Countries with relatively high government consumption and low Gini coefficient of income distribution in 2016-19

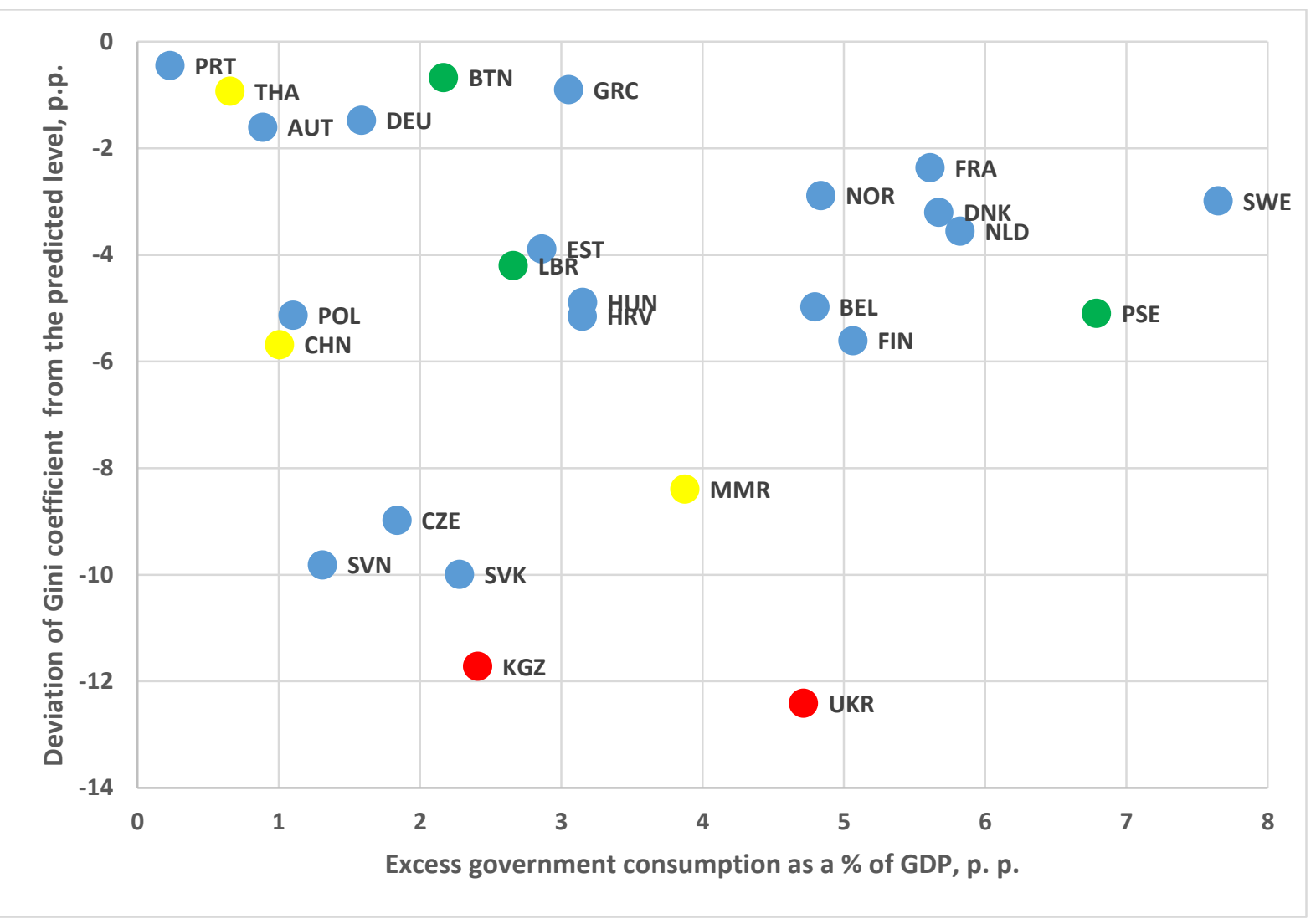

Source: WDI (see Appendix).

For the longer period (2011-19) there are more countries in the first group (low inequalities and high government consumption): Bosnia and Herzegovina, Iceland, Italy and the UK in Europe (+ European offshoots - Australia and Canada); Japan in East Asia; and Algeria, Burkina Faso, Fiji, Guinea, Iraq, Timor-Leste, Tunisia elsewhere (fig. 16; Table 2 of the Appendix). Whereas the second group (high inequalities and low government consumption) is being supplemented by SSA countries (Benin, Cabo Verde, Cameroon, Chad, Comoros, Congo, Cote D’Ivoire, Kenya, Malawi, Ruanda, Zambia), LA countries (Bolivia, Costa Rica, El Salvador, Guatemala, Nicaragua, Uruguay) and 'outliers" (Bhutan, Bulgaria, Georgia, Indonesia, Malaysia, Philippines). 
Fig. 16. Countries with high/low government consumption and low/high Gini coefficient of income distribution (2011-19 data)

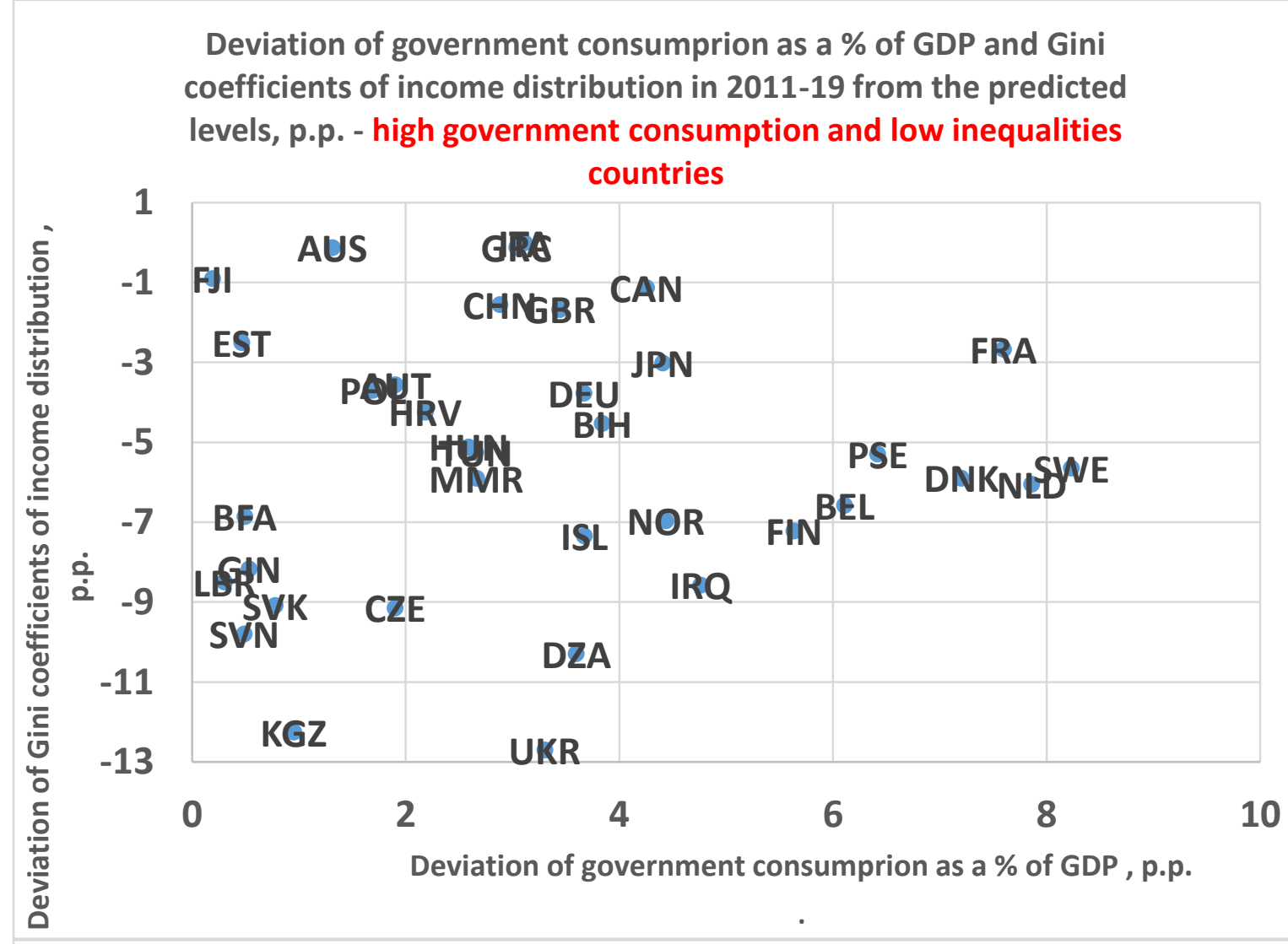

Deviation of government consumprion as a \% of GDP and Gini coefficients of income distribution in 2011-19 from the predicted levels, p.p. - low government consumption and high inequalities

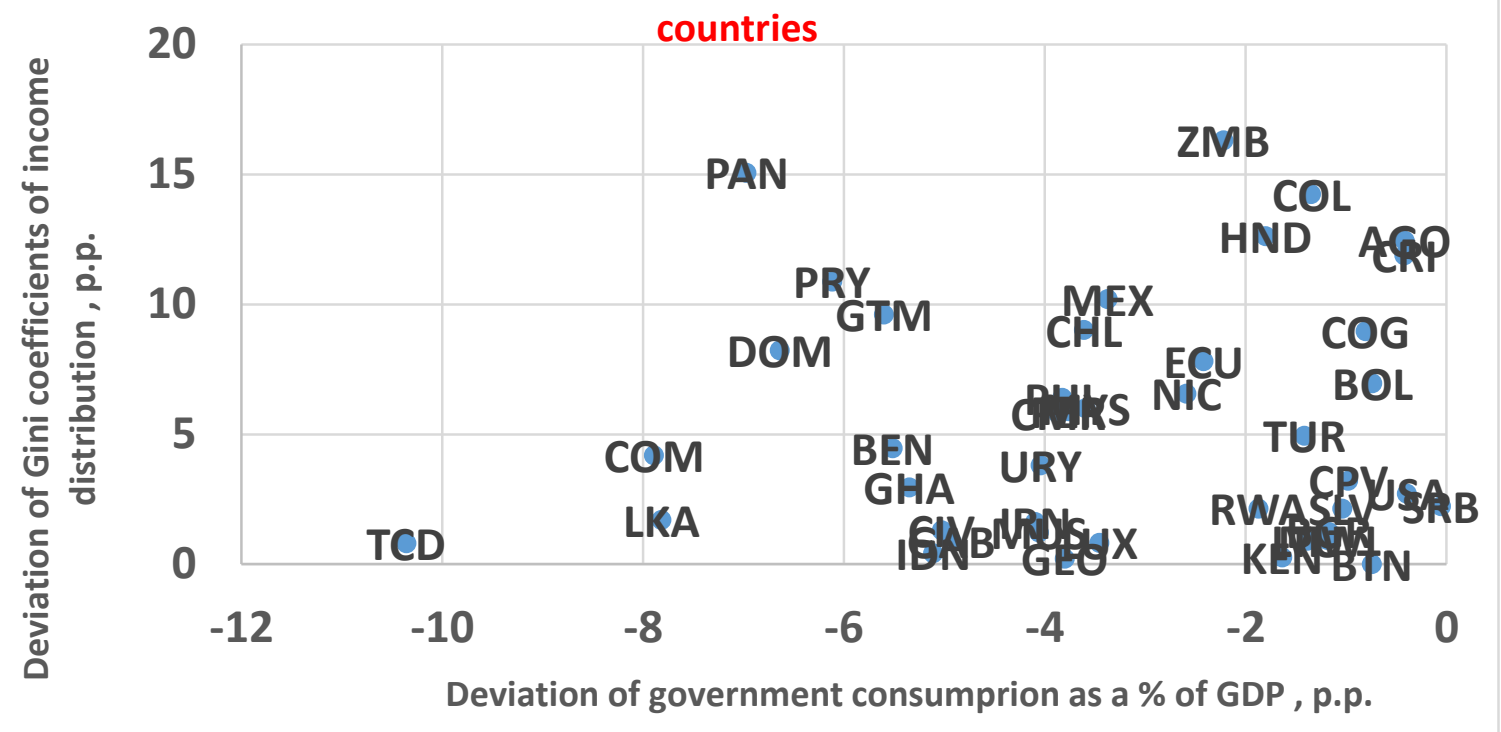

Source: WDI (see Appendix). 
Thus East Asia and Europe in most cases appear to be in the same group of countries with relatively low inequalities and big governments with strong institutional capacity, whereas LA and SSA and USA are in the opposite group of countries with relatively high inequalities and small governments with weak institutional capacity. Trust of the public in the government institutions is usually high in developing countries of East Asia, but low to moderate in Europe and the US.

If such commonalities between East Asia and Europe really exist, this could be a contribution to the Variety of Capitalism literature (Lee, 2020). The collectivist economic model based on low inequalities and big and efficient government appears to be most competitive in terms of catch up development and possibly in terms of innovative growth at the technological frontier and beyond. This low inequality-strong state model is found in developed world (Europe and Japan) and in developing countries (China, ASEAN). It is inherently consistent and has the potential to become the dominant one in other regions.

\section{Concluding remarks}

The low inequality - big government model comes from two different historical trajectories. The European model could be traced back to the $16^{\text {th }}$ century, but emerged in its current form only in the $20^{\text {th }}$ century. Before the $16^{\text {th }}$ century all countries had roughly the same per capita income, low savings rate and virtually zero growth rates. Only the destruction of the collectivist institutions (community) in the $16^{\text {th }}$ century and beyond leading to the growth in inequality allowed the West to raise the savings and investment rates and capital/labor ratio. The result was the acceleration of growth rates of productivity and per capita income by the order of magnitude, but it came at a price: high inequality led to the weakening of the state institutions - in particular the murder rate was in double digits per 100,000 of inhabitants in the $14^{\text {th }}$ to $17^{\text {th }}$ centuries, and life expectancy in the $16-17^{\text {th }}$ century fell (Popov, 2009).

This corruption of state institutions, however, was relatively short-lived: the murder rate in Western Europe fell to the current levels (single digits per 100,000 inhabitants) by the $18-19^{\text {th }}$ century (Popov, $2009 ; 2014)$. And in the $20^{\text {th }}$ century, especially after the Second World War, income inequalities in 
Western countries declined dramatically due to the proliferation of the big government, social and welfare programs - this was the response to the competition from the world socialism with free health care and education, strong social guarantees and low income inequalities (Popov, Jomo, 2015).

In the Global South the collectivist model emerged in a different way. Since the $16^{\text {th }}$ century the Western model of growth was adopted in many developing countries (through colonialism, like in Latin America and Sub-Sahara Africa, or via voluntary Westernization in an attempt to catch up with the West, like in the Russian Empire). Such a proliferation of the Western model has resulted in the destruction of traditional institutions, increase in income inequality, and worsening of starting positions for catch-up development. This group of countries replicated the Western exit from the Malthusian trap - they experienced immediate increase in income differentiation, the rise in savings and investment rates and in the growth of productivity, but at a price of rising social inequality and deterioration of institutional capacities.

Other developing countries (East Asia, and to an extent - South Asia, and Middle East and North Africa) were less affected by colonialism and managed to retain their traditional institutions. This delayed the transition to modern economic growth until mid- $20^{\text {th }}$ century, but allowed to preserve good starting position for economic growth - low inequality and strong institutions. Eventually slow technical progress allowed them to find another (and less painful) exit from the Malthusian trapincreased income permitted to raise the share of investment in GDP without major increase in income inequality, without worsening of institutional capacity and decrease in life expectancy.

This less Westernized region of the developing world became another reincarnation of the low inequalities - big government collectivist economic model. It turned into the fastest growing region of the developing world and started to catch up with the Western levels of per capita income due to its fast growth of productivity, not due to the favorable terms of trade shifts (like some oil exporting nations). Japan, a developing country in 1950 (less than 18\% of the US per capita income), slowed down since the 1990s, and Hong Kong slowed down since 2004, but other East Asian dragons - South Korea, Taiwan, Singapore- continued to grow at record rates bridging the gap with the US income 
level. Singapore even surpassed the US levels of GDP per capita (fig. 17). ASEAN countries and China are following suite.

Fig. 17. PPP GDP per capita in some East Asian countries as a \% of the US level
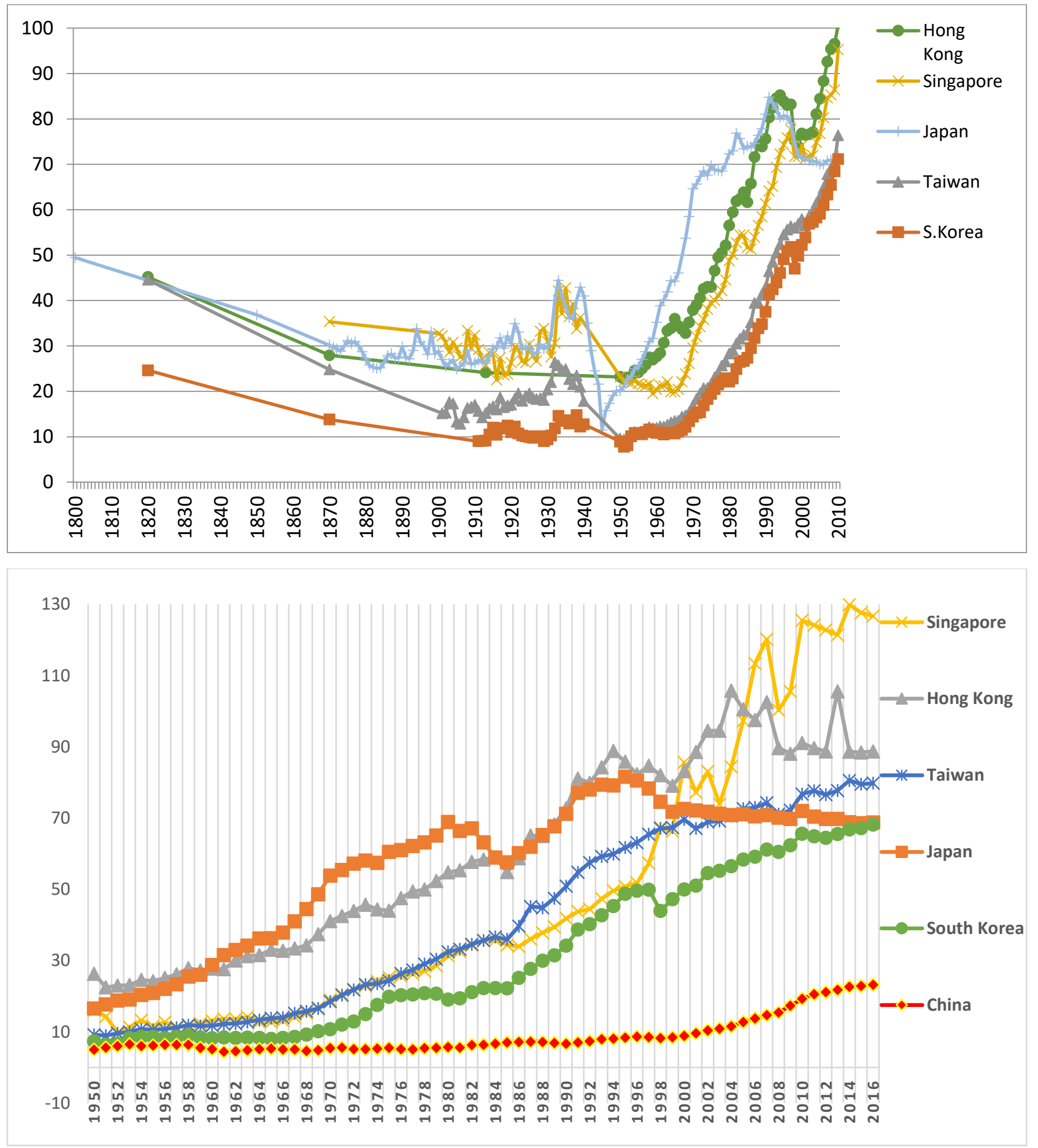

Source: Maddison Project Database, 2018. 
The European collectivist economic model may be experiencing difficulties since the 1980s. Europe in 1923-33 and after the Second World War and until the 1980s was the fastest growing part of the developed world, growing faster than the US. Since the 1980s, though, growth rates of Western Europe have slowed down, and its relative per capita income stagnated at a level of about 70\% of the US level (fig. 18).

Fig. 18. PPP GDP per capita (in 1990 International Geary-Khamis dollars) as a \% of the US level

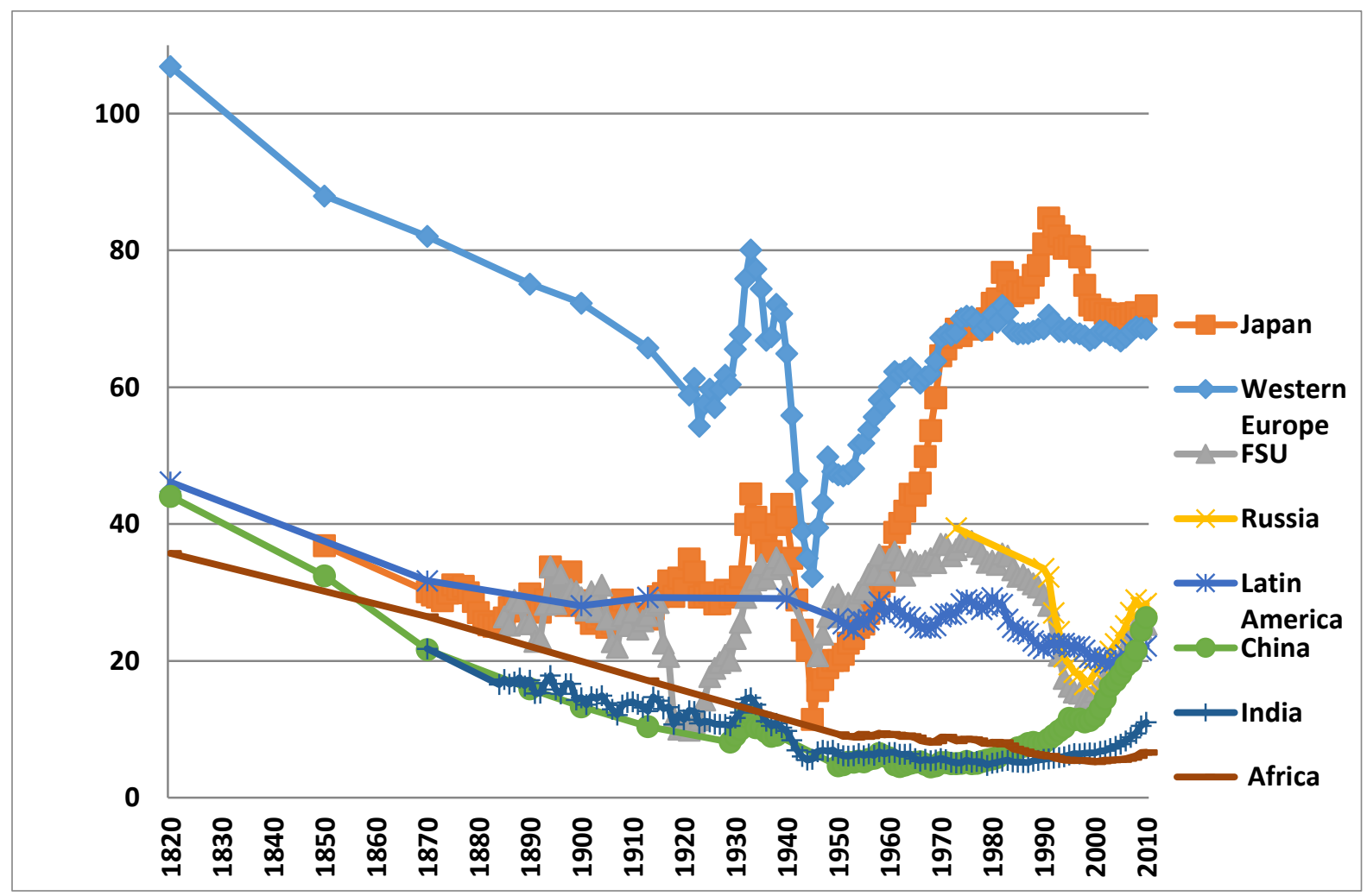

Source: Maddison Project Database, 2018.

One possible reason for these difficulties is the increase in inequalities taking place since the early 1980s (fig. 19). Even before the collapse of the Berlin wall, the USSR and East European countries lost social dynamism and were no longer perceived as a threat by the West (Popov, Jomo, 2015), so 
the need to contain the increase of inequalities to remain competitive vis-à-vis the world communism disappeared. But the growing inequalities created domestic problems by undermining the growth potential.

Fig. 19. Income inequalities in developed and developing countries since 1820

Gini coefficient of income distribution in developed countries in $1820-2000, \%$
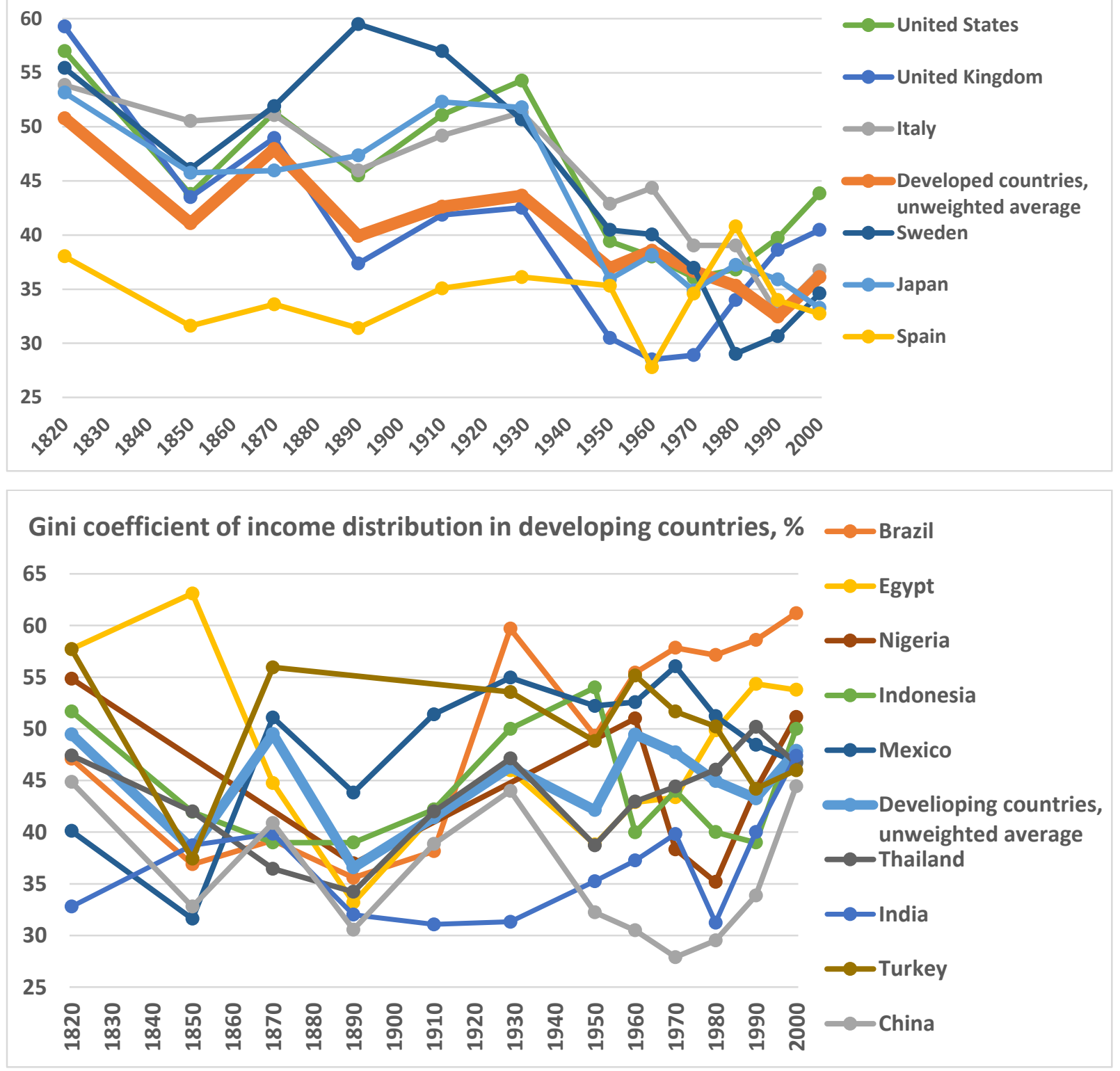


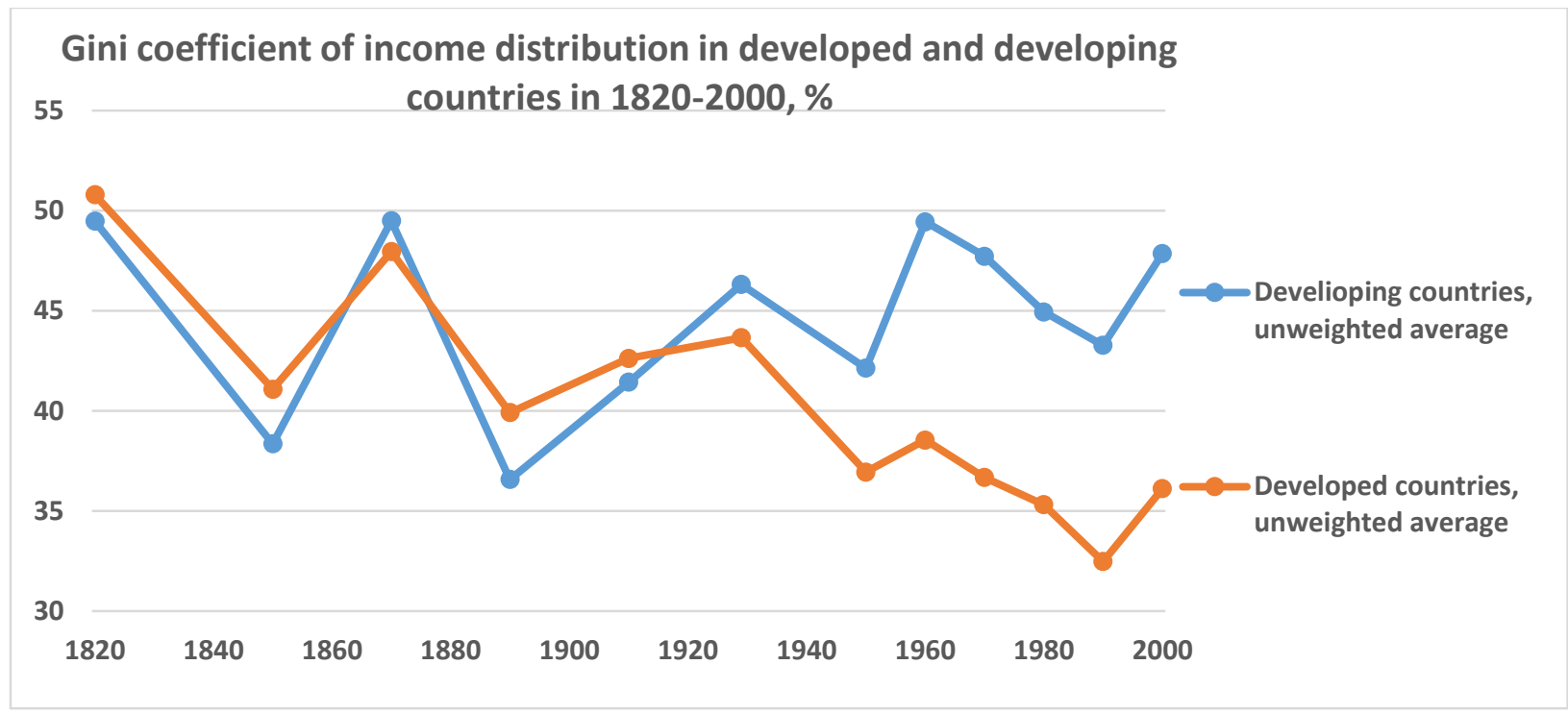

Source: Clio-Infra database. Https://clio-infra.eu/Indicators/IncomeInequality.html\#. Developed unweighted average for 33 countries; developing - unweeighted average of 93 countries.

As fig. 19 suggests, there was an increase in inequalities in recent decades in most countries, developed and developing. But developing countries as a group did not experience the reduction of inequalities in the 1930s-80s that was observed in developed countries. Europe and East Asia are still the regions with lowest relative inequalities in the world, but this could change in the future, so the growth potential of the low inequality - big government - high state capacity collectivist economic model may be jeopardized. Besides, it remains to be seen whether the collectivist model will be competitive at the technological frontier, if and when the productivity levels in these countries will become the highest in the world. 


\section{APPENDIX}

Table 1. General government final consumption (\% of GDP), Gini coefficient of income distribution (\%), PPP GDP and PPP GDP per capita (constant 2017 international dollars), average for 2016-19

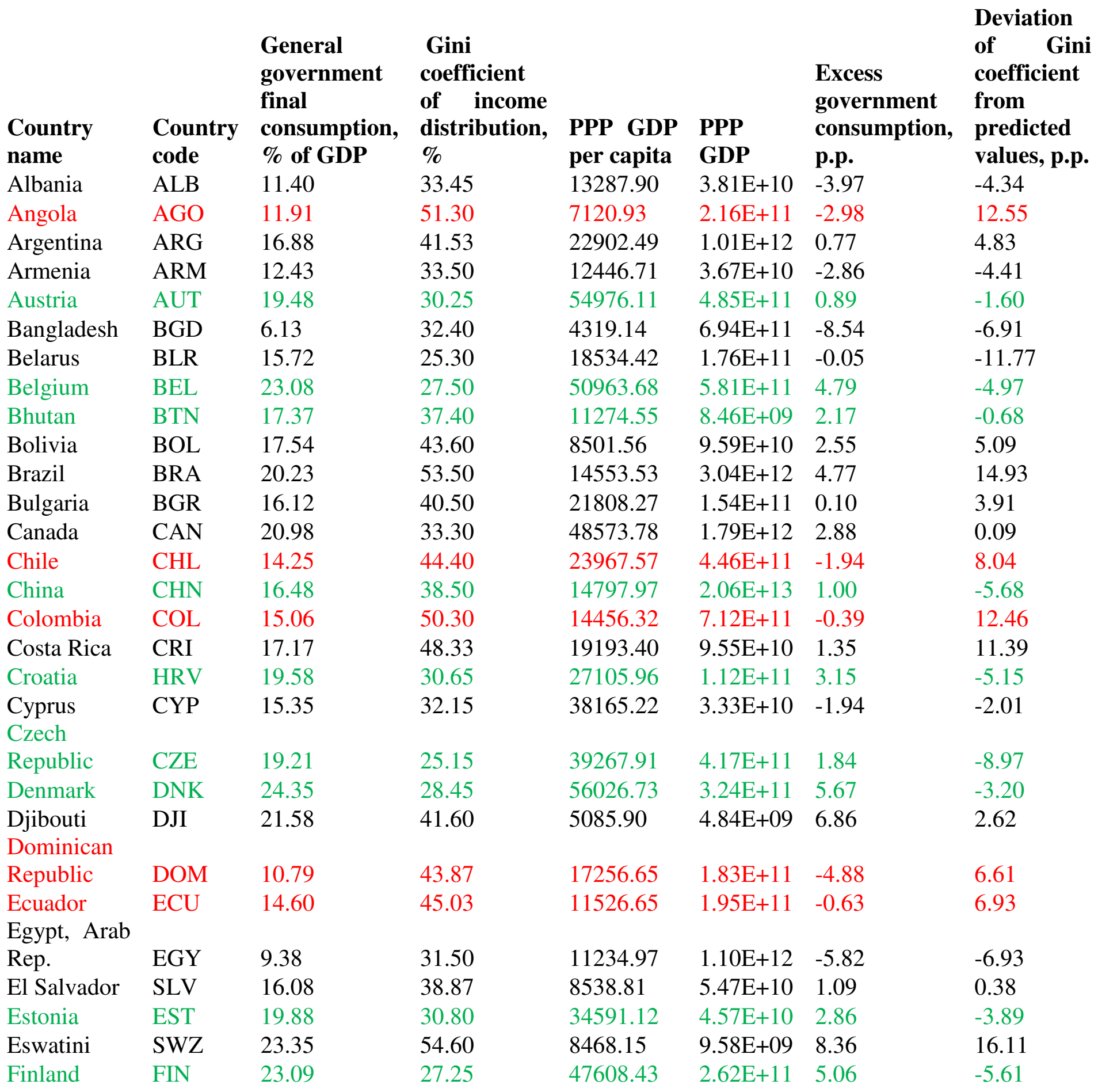




\begin{tabular}{|c|c|c|c|c|c|c|c|}
\hline France & FRA & 23.44 & 31.75 & 45121.38 & $3.02 \mathrm{E}+12$ & 5.61 & -2.36 \\
\hline Gabon & GAB & 12.36 & 38.00 & 15015.27 & $3.14 \mathrm{E}+10$ & -3.14 & 0.46 \\
\hline Georgia & GEO & 13.84 & 36.97 & 13950.69 & $5.20 \mathrm{E}+10$ & -1.57 & -0.73 \\
\hline Germany & DEU & 20.05 & 31.90 & 53260.11 & $4.41 \mathrm{E}+12$ & 1.58 & -1.47 \\
\hline Ghana & GHA & 9.16 & 43.50 & 5081.96 & $1.50 \mathrm{E}+11$ & -5.56 & 4.48 \\
\hline Greece & GRC & 19.63 & 34.70 & 28928.52 & $3.11 \mathrm{E}+11$ & 3.05 & -0.90 \\
\hline Honduras & HND & 13.67 & 51.23 & 5589.46 & $5.32 \mathrm{E}+10$ & -1.09 & 12.31 \\
\hline Hungary & HUN & 19.86 & 30.45 & 30695.78 & $3.00 \mathrm{E}+11$ & 3.15 & -4.89 \\
\hline Indonesia & IDN & 9.10 & 38.17 & 11162.69 & $2.97 \mathrm{E}+12$ & -6.10 & -0.88 \\
\hline \multicolumn{8}{|c|}{ Iran, Islamic } \\
\hline Rep. & IRN & 12.65 & 40.40 & 13650.54 & $1.11 \mathrm{E}+12$ & -2.74 & 2.32 \\
\hline Ireland & IRL & 12.04 & 32.80 & 80353.68 & $3.90 \mathrm{E}+11$ & -8.52 & 4.68 \\
\hline Israel & ISR & 22.57 & 39.00 & 39256.93 & $3.46 \mathrm{E}+11$ & 5.20 & 4.90 \\
\hline Italy & ITA & 18.87 & 35.55 & 41893.30 & $2.53 \mathrm{E}+12$ & 1.29 & 1.13 \\
\hline Kazakhstan & $\mathrm{KAZ}$ & 9.91 & 27.35 & 25242.39 & $4.59 \mathrm{E}+11$ & -6.38 & -8.83 \\
\hline Kosovo & $\mathrm{XKX}$ & 13.92 & 27.85 & 10743.37 & $1.92 \mathrm{E}+10$ & -1.24 & -10.31 \\
\hline \multicolumn{8}{|l|}{ Kyrgyz } \\
\hline Republic & KGZ & 17.14 & 27.27 & 5086.33 & $3.19 \mathrm{E}+10$ & 2.41 & -11.72 \\
\hline Latvia & LVA & 14.96 & 29.50 & 20741.35 & $7.61 \mathrm{E}+11$ & -0.98 & -7.43 \\
\hline Lesotho & LSO & 39.52 & 44.90 & 2769.69 & $5.82 \mathrm{E}+09$ & 24.97 & 5.58 \\
\hline Liberia & LBR & 17.11 & 35.30 & 1489.21 & 7.09E+09 & 2.66 & -4.20 \\
\hline Lithuania & LTU & 16.61 & 37.85 & 34635.10 & $9.77 \mathrm{E}+10$ & -0.41 & 3.15 \\
\hline Luxembourg & LUX & 16.52 & 33.95 & 113741.90 & $6.84 \mathrm{E}+10$ & -6.62 & 10.80 \\
\hline Malawi & MWI & 14.22 & 44.70 & 1041.10 & $1.87 \mathrm{E}+10$ & -0.20 & 5.13 \\
\hline Maldives & MDV & 15.68 & 31.30 & 18492.32 & $9.35 \mathrm{E}+09$ & -0.08 & -5.72 \\
\hline Malta & MLT & 16.13 & 29.15 & 42798.56 & $2.05 \mathrm{E}+10$ & -1.52 & -4.33 \\
\hline Mauritius & MUS & 15.31 & 36.80 & 21785.12 & $2.76 \mathrm{E}+10$ & -0.71 & 0.25 \\
\hline Mexico & MEX & 11.64 & 45.85 & 19817.30 & $2.49 \mathrm{E}+12$ & -4.23 & 8.22 \\
\hline Moldova & MDA & 14.81 & 25.97 & 12004.10 & $3.27 \mathrm{E}+10$ & -0.45 & -12.01 \\
\hline Mongolia & MNG & 12.79 & 32.50 & 11621.14 & $3.65 \mathrm{E}+10$ & -2.45 & -5.53 \\
\hline Myanmar & MMR & 18.58 & 30.70 & 4848.54 & $2.60 \mathrm{E}+11$ & 3.87 & -8.39 \\
\hline Netherlands & NLD & 24.47 & 28.35 & 55677.27 & $9.57 \mathrm{E}+11$ & 5.82 & -3.55 \\
\hline Nigeria & NGA & 5.32 & 35.10 & 5191.46 & $1.00 \mathrm{E}+12$ & -9.42 & -4.18 \\
\hline Norway & NOR & 24.05 & 27.75 & 62979.21 & $3.33 \mathrm{E}+11$ & 4.84 & -2.89 \\
\hline Panama & PAN & 11.50 & 49.83 & 30575.13 & $1.27 \mathrm{E}+11$ & -5.20 & 14.54 \\
\hline Paraguay & PRY & 11.24 & 47.63 & 12571.93 & $8.69 \mathrm{E}+10$ & -4.07 & 9.72 \\
\hline Peru & PER & 13.20 & 43.23 & 12635.12 & $4.01 \mathrm{E}+11$ & -2.11 & 5.23 \\
\hline Poland & POL & 17.83 & 30.45 & 30982.46 & $1.18 \mathrm{E}+12$ & 1.10 & -5.13 \\
\hline Portugal & PRT & 17.16 & 34.50 & 33487.80 & $3.45 \mathrm{E}+11$ & 0.23 & -0.44 \\
\hline Romania & ROU & 16.24 & 35.20 & 27724.37 & $5.41 \mathrm{E}+11$ & -0.24 & -0.65 \\
\hline Russian & & & & & & & \\
\hline Federation & RUS & 16.11 & 35.85 & 26207.44 & $6.16 \mathrm{E}+11$ & -0.26 & -0.25 \\
\hline Rwanda & RWA & 15.15 & 43.70 & 2060.35 & $2.51 \mathrm{E}+10$ & 0.66 & 4.28 \\
\hline Serbia & SRB & 16.33 & 37.50 & 17078.44 & $1.20 \mathrm{E}+11$ & 0.67 & 0.24 \\
\hline
\end{tabular}




$\begin{array}{llllllll}\begin{array}{l}\text { Sierra Leone } \\ \text { Slovak }\end{array} & \text { SLE } & 10.12 & 35.70 & 1658.68 & 1.26 \mathrm{E}+10 & -4.35 & -3.78 \\ \text { Republic } & \text { SVK } & 19.05 & 25.20 & 31429.72 & 1.71 \mathrm{E}+11 & 2.28 & -9.99 \\ \text { Slovenia } & \text { SVN } & 18.53 & 24.50 & 37228.00 & 7.72 \mathrm{E}+10 & 1.31 & -9.81 \\ \text { Spain } & \text { ESP } & 18.80 & 35.25 & 39840.08 & 1.86 \mathrm{E}+12 & 1.38 & 0.74 \\ \text { Sri Lanka } & \text { LKA } & 8.89 & 39.80 & 12703.57 & 2.74 \mathrm{E}+11 & -6.43 & 1.85 \\ \text { Sweden } & \text { SWE } & 26.08 & 29.20 & 52810.36 & 5.34 \mathrm{E}+11 & 7.65 & -2.99 \\ \text { Switzerland } & \text { CHE } & 11.94 & 32.85 & 67704.23 & 5.74 \mathrm{E}+11 & -7.64 & 2.82 \\ \text { Tanzania } & \text { TZA } & 8.78 & 40.50 & 2555.60 & 1.38 \mathrm{E}+11 & -5.75 & 1.11 \\ \text { Thailand } & \text { THA } & 16.36 & 36.60 & 17691.21 & 1.23 \mathrm{E}+12 & 0.65 & -0.93 \\ \text { Turkey } & \text { TUR } & 14.83 & 41.73 & 27926.82 & 2.28 \mathrm{E}+12 & -1.67 & 5.35 \\ \text { Uganda } & \text { UGA } & 8.21 & 42.80 & 2114.92 & 8.88 \mathrm{E}+10 & -6.28 & 3.36 \\ \text { Ukraine } & \text { UKR } & 19.99 & 25.70 & 12138.51 & 5.14 \mathrm{E}+11 & 4.71 & -12.41 \\ \text { United } & & & & & & 0.82 \\ \text { Kingdom } & \text { GBR } & 18.78 & 34.80 & 46044.63 & 3.05 \mathrm{E}+12 & 0.87 & 3.87 \\ \begin{array}{l}\text { United } \\ \text { States }\end{array} & \text { USA } & 14.07 & 41.10 & 60783.55 & 1.98 \mathrm{E}+13 & -4.97 & 3.00 \\ \text { Uruguay } & \text { URY } & 14.67 & 39.63 & 21334.73 & 7.35 \mathrm{E}+10 & -1.31 & -3.37 \\ \begin{array}{l}\text { Vietnam } \\ \text { West Bank }\end{array} & \text { VNM } & 6.49 & 35.50 & 7387.80 & 7.03 \mathrm{E}+11 & -8.42 & -5.10 \\ \text { and Gaza } & \text { PSE } & 21.61 & 33.70 & 6344.71 & 2.87 \mathrm{E}+10 & 6.79 & \end{array}$

Note: Excess government consumption is computed as a residual from regression of general final government consumption as a \% of GDP on PPP GDP and PPP GDP per capita. Deviation of Gini coefficient from predicted values is computed as a residual from regression of actual Gini coefficient on PPP GDP and PPP GDP per capita.

Figures in green are for countries with positive excess government consumption and negative deviation of Gini coefficients from predicted values. Figures in red are for countries with negative excess government consumption and positive deviation of Gini coefficients from predicted values.

Source: WDI database. 
Table 2. General government final consumption (\% of GDP), Gini coefficient of income distribution (\%), PPP GDP and PPP GDP per capita (constant 2017 international dollars), average for 2011-19

Countries with high government consumption and low Gini coefficient

\begin{tabular}{|c|c|c|c|c|c|c|c|}
\hline Country & $\begin{array}{l}\text { Country } \\
\text { Code }\end{array}$ & $\begin{array}{l}\text { General } \\
\text { government } \\
\text { final } \\
\text { consumption, } \\
\% \text { of GDP }\end{array}$ & $\begin{array}{l}\text { Gini } \\
\text { coefficient } \\
\text { of income } \\
\text { distribution, } \\
\%\end{array}$ & $\begin{array}{l}\text { PPP GDP } \\
\text { per } \\
\text { capita }\end{array}$ & $\begin{array}{l}\text { PPP } \\
\text { GDP, } \\
\text { billion } \\
\$\end{array}$ & $\begin{array}{l}\text { Excess } \\
\text { government } \\
\text { consumptio } \\
\text { n, p.p. }\end{array}$ & $\begin{array}{l}\text { Deviation of } \\
\text { Gini } \\
\text { coefficient } \\
\text { from } \\
\text { predicted } \\
\text { values, p.p. }\end{array}$ \\
\hline Algeria & DZA & 19.5 & 27.6 & 11506.3 & 458.1 & 3.6 & -10.3 \\
\hline Australia & AUS & 18.3 & 34.4 & 48039.4 & 1147 & 1.3 & -0.1 \\
\hline Austria & AUT & 19.7 & 30.5 & 54044.5 & 467 & 1.9 & -3.6 \\
\hline Belgium & BEL & 23.6 & 27.7 & 49721.2 & 560.4 & 6.1 & -6.6 \\
\hline $\begin{array}{l}\text { Bosnia and } \\
\text { Herzegovina }\end{array}$ & $\mathrm{BIH}$ & 21.6 & 33.0 & 12817.4 & 44.12 & 3.8 & -4.5 \\
\hline Burkina Faso & BFA & 16.1 & 35.3 & 1961.3 & 35.76 & 0.5 & -6.9 \\
\hline Canada & CAN & 20.9 & 33.6 & 47695.2 & 1710 & 4.3 & -1.1 \\
\hline China & $\mathrm{CHN}$ & 16.1 & 40.1 & 12781.7 & 17570 & 2.9 & -1.6 \\
\hline Croatia & HRV & 20.2 & 31.6 & 25343.6 & 106 & 2.2 & -4.2 \\
\hline Czech Republic & CZE & 19.3 & 25.9 & 36626.3 & 387 & 1.9 & -9.1 \\
\hline Denmark & DNK & 25.3 & 28.2 & 53754.0 & 306 & 7.2 & -5.9 \\
\hline Estonia & EST & 19.4 & 32.8 & 31933.7 & 42.15 & 0.5 & -2.5 \\
\hline Fiji & FJI & 19.0 & 36.7 & 12393.8 & 10.82 & 0.2 & -0.9 \\
\hline Finland & FIN & 23.7 & 27.2 & 46454.4 & 254.1 & 5.6 & -7.2 \\
\hline France & FRA & 23.7 & 32.5 & 44039.2 & 2924 & 7.6 & -2.7 \\
\hline Germany & DEU & 19.7 & 31.3 & 51743.5 & 4228 & 3.7 & -3.8 \\
\hline Greece & GRC & 20.3 & 35.5 & 28673.0 & 311.6 & 3.0 & -0.1 \\
\hline Guinea & GIN & 16.5 & 33.7 & 2205.4 & 25.54 & 0.5 & -8.2 \\
\hline Hungary & HUN & 20.0 & 30.5 & 28147.0 & 277.1 & 2.6 & -5.1 \\
\hline
\end{tabular}




\begin{tabular}{|c|c|c|c|c|c|c|c|}
\hline Iceland & ISL & 23.9 & 26.7 & 52065.3 & 17.48 & 3.7 & -7.3 \\
\hline Iraq & IRQ & 20.7 & 29.5 & 10586.6 & 374.7 & 4.8 & -8.6 \\
\hline Italy & ITA & 19.3 & 35.2 & 41487.1 & 2501 & 3.1 & 0.0 \\
\hline Japan & JPN & 20.0 & 32.9 & 39635.1 & 5037 & 4.4 & -3.0 \\
\hline $\begin{array}{l}\text { Kyrgyz } \\
\text { Republic }\end{array}$ & KGZ & 17.8 & 27.7 & 4788.7 & 28.66 & 1.0 & -12.3 \\
\hline Liberia & LBR & 16.9 & 34.3 & 1540.0 & 6.882 & 0.3 & -8.5 \\
\hline Myanmar & MMR & 17.8 & 34.4 & 4245.2 & 223.9 & 2.7 & -5.9 \\
\hline Netherlands & NLD & 25.1 & 28.1 & 53910.5 & 915.5 & 7.9 & -6.0 \\
\hline Norway & NOR & 22.7 & 26.7 & 61882.4 & 320.2 & 4.4 & -7.0 \\
\hline Poland & POL & 18.0 & 32.1 & 28348.1 & 1077 & 1.7 & -3.7 \\
\hline Slovak Republic & SVK & 18.6 & 26.4 & 29425.9 & 159.7 & 0.8 & -9.1 \\
\hline Slovenia & SVN & 19.2 & 25.3 & 34998.8 & 72.31 & 0.5 & -9.8 \\
\hline Sweden & SWE & 25.9 & 28.6 & 51209.4 & 504 & 8.2 & -5.6 \\
\hline Timor-Leste & TLS & 63.8 & 28.7 & 3228.6 & 3.876 & & -12.2 \\
\hline Tunisia & TUN & 19.4 & 32.8 & 10435.0 & 116.9 & 2.7 & -5.3 \\
\hline Ukraine & UKR & 19.1 & 25.1 & 12194.1 & 531.5 & 3.3 & -12.7 \\
\hline $\begin{array}{l}\text { United } \\
\text { Kingdom }\end{array}$ & GBR & 19.6 & 33.5 & 44633.9 & 2907 & 3.4 & -1.7 \\
\hline $\begin{array}{l}\text { West Bank and } \\
\text { Gaza }\end{array}$ & PSE & 23.7 & 34.1 & 6142.4 & 26.29 & 6.4 & -5.3 \\
\hline
\end{tabular}

Most of the countries are from Europe (not highlighted). Asian countries are highlighted in red, MENA countries - in green, other - in blue. 


\section{Countries with low government consumption and high Gini coefficient}

\begin{tabular}{|c|c|c|c|c|c|c|c|}
\hline Country & $\begin{array}{l}\text { Country } \\
\text { Code }\end{array}$ & $\begin{array}{l}\text { General } \\
\text { government } \\
\text { final } \\
\text { consumption, } \\
\text { \% of GDP }\end{array}$ & $\begin{array}{l}\text { Gini } \\
\text { coefficient of } \\
\text { income } \\
\text { distribution, } \\
\%\end{array}$ & $\begin{array}{l}\text { PPP GDP } \\
\text { per capita }\end{array}$ & $\begin{array}{l}\text { PPP } \\
\text { GDP, } \\
\text { billion \$ }\end{array}$ & $\begin{array}{l}\text { Excess } \\
\text { government } \\
\text { consumption, } \\
\text { p.p. }\end{array}$ & $\begin{array}{l}\text { Deviation } \\
\text { of Gini } \\
\text { coefficient } \\
\text { from } \\
\text { predicted } \\
\text { values, } \\
\text { p.p. }\end{array}$ \\
\hline Angola & AGO & 51.3 & 15.5 & 212.0 & 7623.6 & -0.4 & 12.4 \\
\hline Benin & BEN & 45.6 & 10.7 & 31.6 & 2968.9 & -5.5 & 4.5 \\
\hline Bhutan & BTN & 38.1 & 18.1 & & 10194.5 & -0.7 & 0.0 \\
\hline Bolivia & $\mathrm{BOL}$ & 45.7 & 15.9 & 86.1 & 7899.1 & -0.7 & 7.0 \\
\hline Bulgaria & BGR & 37.7 & 16.3 & 143.1 & 19991.8 & -1.2 & 1.2 \\
\hline Cabo Verde & CPV & 42.4 & 17.9 & 3.4 & 6528.2 & -1.0 & 3.2 \\
\hline Cameroon & CMR & 46.6 & 11.8 & 79.9 & 3412.9 & -3.9 & 5.8 \\
\hline Chad & TCD & 43.3 & 5.4 & 24.1 & 1711.1 & -10.4 & 0.8 \\
\hline Chile & $\mathrm{CHL}$ & 45.2 & 13.2 & 421.6 & 23358.4 & -3.6 & 9.0 \\
\hline Colombia & $\mathrm{COL}$ & 51.7 & 14.5 & 665.1 & 13907.5 & -1.3 & 14.2 \\
\hline Comoros & COM & 45.3 & 10.3 & 2.3 & 2997.7 & -7.9 & 4.2 \\
\hline Congo, Rep. & COG & 48.9 & 16.2 & 23.3 & 4821.2 & -0.8 & 9.0 \\
\hline Costa Rica & CRI & 48.6 & 17.3 & 87.9 & 18105.7 & -0.4 & 11.9 \\
\hline Cote d'Ivoire & CIV & 41.5 & 10.8 & 102.6 & 4367.2 & -5.0 & 1.3 \\
\hline $\begin{array}{l}\text { Dominican } \\
\text { Republic }\end{array}$ & DOM & 45.3 & 10.4 & 159.1 & 15422.3 & -6.6 & 8.2 \\
\hline Ecuador & ECU & 45.6 & 14.1 & 188.5 & 11590.6 & -2.4 & 7.8 \\
\hline El Salvador & SLV & 40.8 & 16.1 & 51.7 & 8167.9 & -1.0 & 2.1 \\
\hline Gabon & $\mathrm{GAB}$ & 38.0 & 13.4 & 29.4 & 15146.3 & -4.9 & 0.9 \\
\hline Georgia & GEO & 37.8 & 13.9 & 47.3 & 12693.3 & -3.8 & 0.2 \\
\hline Ghana & GHA & 43.0 & 10.4 & 133.5 & 4768.1 & -5.3 & 3.0 \\
\hline Guatemala & GTM & 48.3 & 10.8 & 125.6 & 8055.7 & -5.6 & 9.6 \\
\hline Honduras & HND & 52.3 & 14.8 & 48 & 5328.2 & -1.8 & 12.6 \\
\hline
\end{tabular}




\begin{tabular}{|c|c|c|c|c|c|c|c|}
\hline \multirow{2}{*}{$\begin{array}{l}\text { Indonesia } \\
\text { Iran, Islamic } \\
\text { Rep. }\end{array}$} & IDN & 39.1 & 9.3 & 2642.0 & 10202.1 & -5.1 & 0.4 \\
\hline & IRN & 39.3 & 11.3 & 1046.0 & 13308.5 & -4.1 & 1.6 \\
\hline Kenya & KEN & 40.8 & 13.6 & 185.0 & 3846.6 & -1.6 & 0.3 \\
\hline Lithuania & LTU & 36.2 & 17.0 & 90.4 & 31256.3 & -1.4 & 0.9 \\
\hline Luxembourg & LUX & 33.0 & 16.7 & 63.1 & 110645.4 & -3.5 & 0.8 \\
\hline Malawi & MWI & 44.7 & 14.2 & 17.1 & 1020.3 & -1.2 & 0.9 \\
\hline Malaysia & MYS & 42.1 & 12.8 & 753.3 & 24788.5 & -3.6 & 6.0 \\
\hline Mauritius & MUS & 37.7 & 14.7 & 25.3 & 20036.4 & -4.1 & 1.2 \\
\hline Mexico & MEX & 47.3 & 11.9 & 2346.0 & 19250.7 & -3.4 & 10.2 \\
\hline Nicaragua & NIC & 46.2 & 14.3 & 34.1 & 5464.0 & -2.6 & 6.6 \\
\hline Panama & PAN & 50.7 & 11.1 & 112.2 & 28126.1 & -7.0 & 15.1 \\
\hline Paraguay & PRY & 48.6 & 11.1 & 79.1 & 11792.7 & -6.1 & 10.9 \\
\hline Peru & PER & 43.7 & 12.3 & 368.8 & 12005.0 & -3.8 & 5.9 \\
\hline Philippines & $\mathrm{PHL}$ & 45.5 & 11.1 & 758.3 & 7398.3 & -3.8 & 6.4 \\
\hline Rwanda & RWA & 44.4 & 14.1 & 21.6 & 1877.6 & -1.9 & 2.1 \\
\hline Serbia & SRB & 39.2 & 17.3 & 113.4 & 16009.5 & -0.1 & 2.2 \\
\hline Sri Lanka & LKA & 39.5 & 8.5 & 247.4 & 11740.3 & -7.8 & 1.7 \\
\hline Turkey & TUR & 41.2 & 14.3 & 2032.0 & 25795.3 & -1.4 & 4.9 \\
\hline United States & USA & 40.9 & 14.7 & 18720.0 & 58402.9 & -0.4 & 2.7 \\
\hline Uruguay & URY & 40.2 & 14.0 & 69.9 & 20473.2 & -4.0 & 3.8 \\
\hline Zambia & ZMB & 57.1 & 13.8 & 54.5 & 3419.9 & -2.2 & 16.3 \\
\hline
\end{tabular}

Note: Excess government consumption is computed as a residual from regression of general final government consumption as a \% of GDP on PPP GDP and PPP GDP per capita. Deviation of Gini coefficient from predicted values is computed as a residual from regression of actual Gini coefficient on PPP GDP and PPP GDP per capita. European countries highlighted in blue, Asia countries - in red; all other countries are either in SSA or Americas (LA and the USA).

Source: WDI database. 


\section{References}

Inglehart R., Ch. Welzel (2013). "The WVS Cultural Map of the World". World Value Survey.

Lee, K. (2019). Varieties of Capitalism and re-thinking the East Asian model of economic growth after the Covid-19: Rebalancing shareholder and stakeholder capitalism. - Seoul Journal of Economics Vol. 33, No. 4, pp.487-504.

Maddison Project Database (2018).

https://www.rug.nl/ggdc/historicaldevelopment/maddison/releases/maddison-project-database2020?lang=en

Milanovic, B. (2012). Does economic inequality set limits to EU expansion? Conference on Sovereign Insolvency, Opatija, Croatia, November 2012.

Novokmet, F., Th. Piketty, L. Yang, and G. Zucman (2018). From Communism to Capitalism: Private versus Public Property and Inequality in China and Russia. AEA Papers and Proceedings 2018, 108: 109-113. Https://doi.org/10.1257/pandp.20181074.

Popov, V. (2009). Why the West Became Rich before China and Why China Has Been Catching Up with the West since 1949: Another Explanation of the "Great Divergence" and "Great Convergence" Stories. - NES/CEFIR Working paper \# 132, October 2009.

Popov, V. (2011a). Is the Chinese variety of capitalism really unique? CEFIR and NES working paper \#156.

Popov, V. (2011b). Developing new measurements of state institutional capacity. PONARS Eurasia Policy Memo No. 158.

Popov, V. (2014). Mixed fortunes: An economic history of China, Russia and the West. Oxford, UK: Oxford University Press. 
Popov, V. (2015). Catching Up: Developing Countries in Pursuit of Growth. MPRA Paper No. 65878, August 2015.

Popov, V., K.S. Jomo (2015). Income Inequalities in Perspective. - Development, Vol. 59, No. 1, 2016.

Popov, V. (2020). Which economic model is more competitive? The West and the South after the Covid-19 pandemic -Seoul Journal of Economics 2020, Vol. 33, No. 4, pp. 505-538.

Rodrik, D. (1998). Why do More Open Economies Have Bigger Governments? Journal of Political Economy, Vol. 106, No. 5 (October 1998), pp. 997-1032

Schneider, F. (2007). Shadow economies and corruption all over the world: New estimates for 145 countries. Economics. Open Access, Open Assessment E-Journal, 2007(9)

World Values Survey. Http://www.worldvaluessurvey.org/WVSDocumentationWV6.jsp .

WDI. World Development Indicators Database. Https://databank.worldbank.org/source/world$\underline{\text { development-indicators }}$ 